\title{
IL-6 promotes nonthyroidal illness syndrome by blocking thyroxine activation while promoting thyroid hormone inactivation in human cells
}

\author{
Simone Magagnin Wajner, ${ }^{1}$ luri Martin Goemann, ${ }^{1}$ Ana Laura Bueno, ${ }^{1}$ \\ P. Reed Larsen, ${ }^{2}$ and Ana Luiza Maia ${ }^{1}$
}

\begin{abstract}
${ }^{1}$ Thyroid Section, Endocrine Division, Hospital de Clínicas de Porto Alegre, Universidade Federal do Rio Grande do Sul, Porto Alegre, Brazil. 2Division of Endocrinology, Diabetes, and Hypertension, Brigham and Women's Hospital and Harvard Medical School, Boston, Massachusetts, USA.
\end{abstract}

\begin{abstract}
Nonthyroidal illness syndrome (NTIS) is a state of low serum $3,5,3^{\prime}$ triiodothyronine $\left(T_{3}\right)$ that occurs in chronically ill patients; the degree of reduction in $T_{3}$ is associated with overall prognosis and survival. Iodothyronine deiodinases are enzymes that catalyze iodine removal from thyroid hormones; type I and II deiodinase (D1 and D2, respectively) convert the prohormone thyroxine $T_{4}$ to active $T_{3}$, whereas the type III enzyme (D3) inactivates $T_{4}$ and $T_{3}$. Increased production of cytokines, including IL-6, is a hallmark of the acute phase of NTIS, but the role of cytokines in altered thyroid hormone metabolism is poorly understood. Here, we measured the effect of IL-6 on both endogenous cofactor-mediated and dithiothreitol-stimulated (DTT-stimulated) cell sonicate deiodinase activities in human cell lines. Active $\mathrm{T}_{3}$ generation by $\mathrm{D} 1$ and $\mathrm{D} 2$ in intact cells was suppressed by IL-6, despite an increase in sonicate deiodinases (and mRNAs). N-acetylcysteine (NAC), an antioxidant that restores intracellular glutathione (GSH) concentrations, prevented the IL-6-induced inhibitory effect on D1- and D2-mediated $T_{3}$ production, which suggests that IL-6 might function by depleting an intracellular thiol cofactor, perhaps GSH. In contrast, IL-6 stimulated endogenous D3mediated inactivation of $\mathrm{T}_{3}$. Taken together, these results identify a single pathway by which IL-6-induced oxidative stress can reduce D1- and D2-mediated $T_{4}$-to- $T_{3}$ conversion as well as increasing D3-mediated $T_{3}$ (and $\mathrm{T}_{4}$ ) inactivation, thus mimicking events during illness.
\end{abstract}

\section{Introduction}

Nonthyroidal illness syndrome (NTIS; also known as sick euthyroid syndrome) refers to characteristic changes in thyroid hormone levels in critically ill patients. The acute phase of critical illness, observed in a variety of clinical situations, is marked by low $3,5,3^{\prime}$ triiodothyronine $\left(T_{3}\right)$ and high serum reverse $T_{3}\left(r T_{3}\right)$. When patients enter the chronic phase of illness, there is also a decrease in circulating $T_{4}$, as well as a further reduction in the $T_{3} / \mathrm{rT}_{3}$ ratio, whereas thyroid-stimulating hormone (TSH) typically remains within the normal range $(1,2)$. Thus, whereas in the initial phase of illness the changes occur primarily in the peripheral metabolism of thyroid hormones, neuroendocrine abnormalities predominate in prolonged illness. Whether and to what extent these changes reflect a protective or a maladaptive process still remains controversial. The degree of reduction in thyroid hormone levels in sick patients, however, is correlated with prognosis and survival $(3,4)$. The pathogenesis of these multifactorial endocrine alterations is not fully understood.

Iodothyronine deiodinase types I (D1, encoded by DIO1), II (D2, encoded by DIO2), and III (D3, encoded by DIO3) are oxireductases that catalyze iodine removal from the outer (D1 and D2) or inner ring (D3) of thyroid hormones (5). Whereas $\mathrm{D} 1$ and $\mathrm{D} 2$ convert $\mathrm{T}_{4}$ to the active hormone $\mathrm{T}_{3}, \mathrm{D} 3$ inactivates both $\mathrm{T}_{4}$ and $\mathrm{T}_{3}$. In humans, $80 \%$ of peripheral $\mathrm{T}_{3}$ originates

Conflict of interest: The authors have declared that no conflict of interest exists. Citation for this article: J Clin Invest. 2011;121(5):1834-1845. doi:10.1172/JCI44678. from deiodination of the prohormone $\mathrm{T}_{4}$ by $\mathrm{D} 1$ and $\mathrm{D} 2$. The most common abnormality in patients with NTIS is a decrease in circulating $\mathrm{T}_{3}$ levels, caused mainly by reduced conversion of $\mathrm{T}_{4}$ to $\mathrm{T}_{3}(6,7)$. However, increased inactivation of thyroid hormone by increased D3 also plays a role, since recent studies of NTIS patients showed robust stimulation of D3 in both liver and skeletal muscle. The increased D3 causes further decreases in serum $\mathrm{T}_{3}$ and increases in serum $\mathrm{rT}_{3}(3,7-9)$. The role of D2 in NTIS is still unclear: some studies report a decrease of D2 activity (3), whereas others are indicative of unaltered (10) or even augmented D2 activity in skeletal muscle of severely ill patients (11). These apparently discrepant results could be partially explained by difficulties in accurately quantitating the low D2 activity in muscle (12).

All 3 deiodinases require an as-yet undefined cofactor, probably a thiol, which acts as a reducing agent releasing iodine from the selenocysteine residue and regenerating the active enzyme. Early studies of D1 suggested that the endogenous cofactor might be glutathione (GSH) or thioredoxin, because both were effective in supporting catalysis (13-15). Little is known of the endogenous cofactor for D2 or D3, although a recent report shows that D2 activity is stimulated by GSH and thioredoxin (16). Of note, most studies have measured deiodinase activity in the presence of dithiothreitol (DTT), which allows only for estimates of the maximal deiodinase activity $\left(V_{\max }\right)$ and does not address in vivo function with the available endogenous cofactor. Thus, even if $V_{\max }$ is normal, endogenous function may be impaired during critical illness. 
A
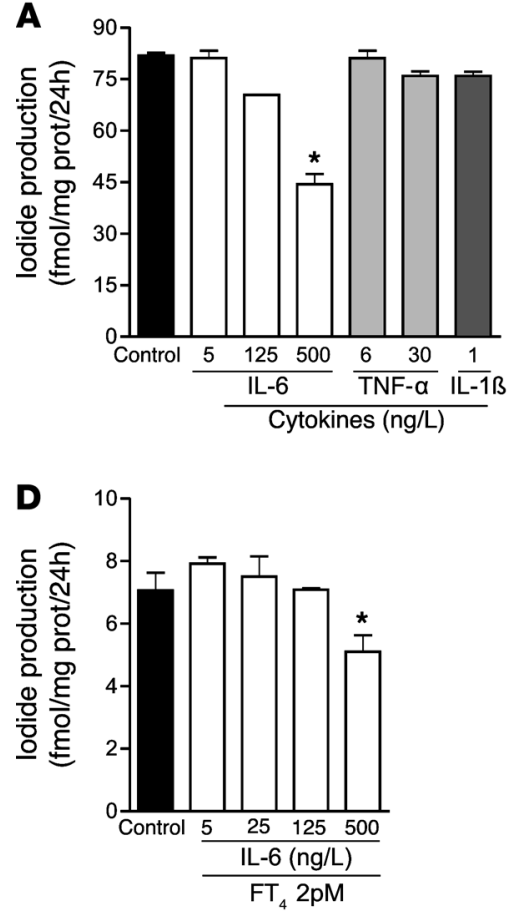

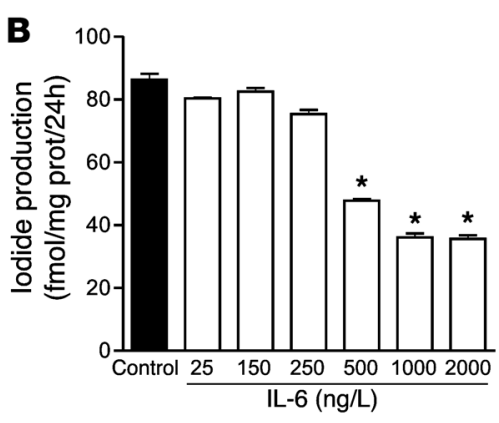

C

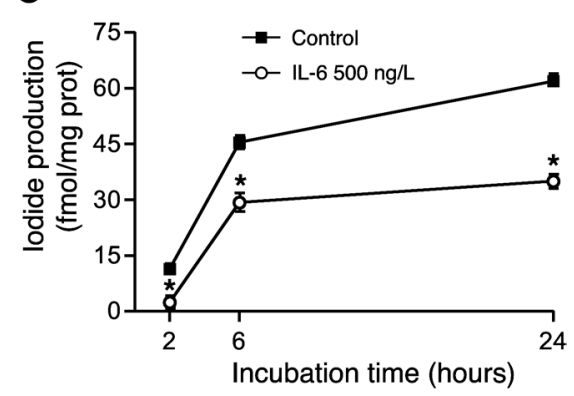

$\mathbf{F}$
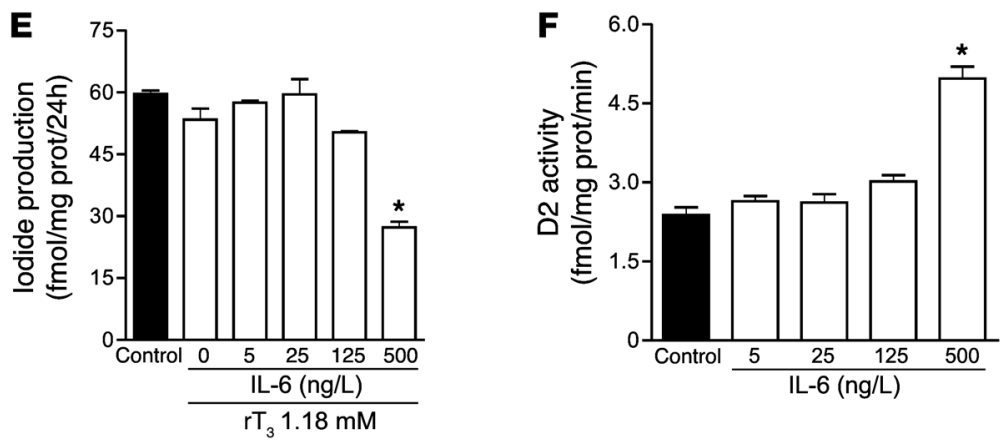

Figure 1

Changes elicited by IL-6 in HEK-293 cells transiently expressing D2. IL-6 concentrations, as observed in critically ill patients, inhibited D2 deiodination by intact cells (A) in a dose-dependent fashion (B), an effect already observed after 2 hours of incubation (C). The effects of IL-6 on intact cell $\mathrm{T}_{3}$ production were unaffected by low $\mathrm{FT}_{4}(\mathbf{D})$ or elevated $\mathrm{rT}_{3}$ levels (E). In contrast, similar doses of IL-6 enhanced D2 activity on DTT-stimulated assay in sonicated cells $(\mathbf{F})$. Data are mean \pm SD of at least 3 independent experiments. The net iodide release in this system is specific and equivalent to $T_{3}$ production (5). ${ }^{*} P<0.001$ versus control.

Given that NTIS occurs in response to virtually any illness or surgical stress, the primary signal is likely to be a factor common to all these conditions. In this context, particular attention has been focused on the cytokines, which are elevated as a generalized response to illness (17). A single dose of IL- 6 given to healthy humans causes a transient decrease in serum $\mathrm{T}_{3}$ and an increase in $\mathrm{rT}_{3}$, changes that are characteristic of the NTIS (18). In hospitalized patients, there is an inverse correlation between serum IL-6 and serum $T_{3}$ concentrations (19-22). Cytokines inhibit the expression and function of D1 in HepG2 human hepatocellular carcinoma cells, whereas studies of rat hepatocyte cells have demonstrated that IL-1 and IL- 6 impair $\mathrm{T}_{3}$-mediated induction of Dio1 mRNA by a mechanism that involves thyroid hormone receptor interaction $(23,24)$. Nonetheless, it seems unlikely that D1 inhibition alone would account for the nearly $70 \%$ decrease in serum $\mathrm{T}_{3}$ levels typical of NTIS patients $(7,10)$, especially since both clinical and experimental data suggest that $\mathrm{D} 2$-catalyzed $\mathrm{T}_{4}$-to- $\mathrm{T}_{3}$ conversion is an important source of circulating $\mathrm{T}_{3}(5,25)$. The results of studies of effects of cytokines on D2 activity in human skeletal muscle cells have been contradictory. At IL- 6 concentrations of $1,000 \mathrm{ng} / \mathrm{l}$, present in many critically ill patients, there was inhibition of D2 activity, whereas no changes occurred at higher concentrations (10,000ng/l; ref. 26). To our knowledge, there are no data available on the effect of cytokines on D3 activity.

In the present study, we used a previously described approach to examine the acute effects of IL- 6 on deiodinase function catalyzed by the endogenous cofactors in human cells expressing endogenous deiodinases, as well as the maximal deiodinase activity of the same cell sonicates in the presence of DTT (5). Cells were exposed to IL- 6 concentrations spanning normal to high ranges $(10,27)$. In this way, we were able to differentiate between the effects of cytokine-induced changes in the endogenous cofactor versus those on the quantities of the deiodinase proteins per se.

\section{Results}

IL-6 decreases D2-mediated deiodination in intact cells. Given the limited information regarding $\mathrm{D} 2$-mediated $\mathrm{T}_{4}$-to- $\mathrm{T}_{3}$ conversion during NTIS, we first exposed HEK-293 cells transiently expressing D2 to various IL- 6 concentrations at physiological free $\mathrm{T}_{4}\left(\mathrm{FT}_{4}\right)$ concentrations $(20 \mathrm{pM})$ and monitored $\mathrm{T}_{3}$ production via ${ }^{125} \mathrm{I}$ release. The production of $\mathrm{T}_{3}$ from outer ring-labeled $\mathrm{T}_{4}$ in intact cells can be analyzed by measuring the level of either $\left[{ }^{125} \mathrm{I}\right] \mathrm{T}_{3}$ or ${ }^{125} \mathrm{I}^{-}$in the medium, since we have previously demonstrated that equimolar amounts of both products are generated in this system (5).

$\mathrm{T}_{3}$ production at IL- 6 concentrations of 5 or $25 \mathrm{ng} / \mathrm{l}$, typical of those in healthy individuals, did not differ from that of controls (Figure 1, A and B). However, a decrease in D2-mediated $\mathrm{T}_{4}$ deiodination was observed when IL- 6 concentrations similar to those in critically ill patients (500 ng/l or higher) were used (Figure 1A). In contrast, 6 or $30 \mathrm{ng} / 1$ of TNF- $\alpha$ or IL- $1 \beta$ caused no changes in D2 activity (Figure 1A), which suggests that, at these concentrations, this effect is specific for IL-6.

The decrease in D2-catalyzed $\mathrm{T}_{4}$-to- $\mathrm{T}_{3}$ conversion induced by IL-6 was dose dependent and already observed after a 2-hour incubation period (Figure 1, B and C). Because NTIS patients often develop hypothyroxinemia, we also measured D2 activity at a low 

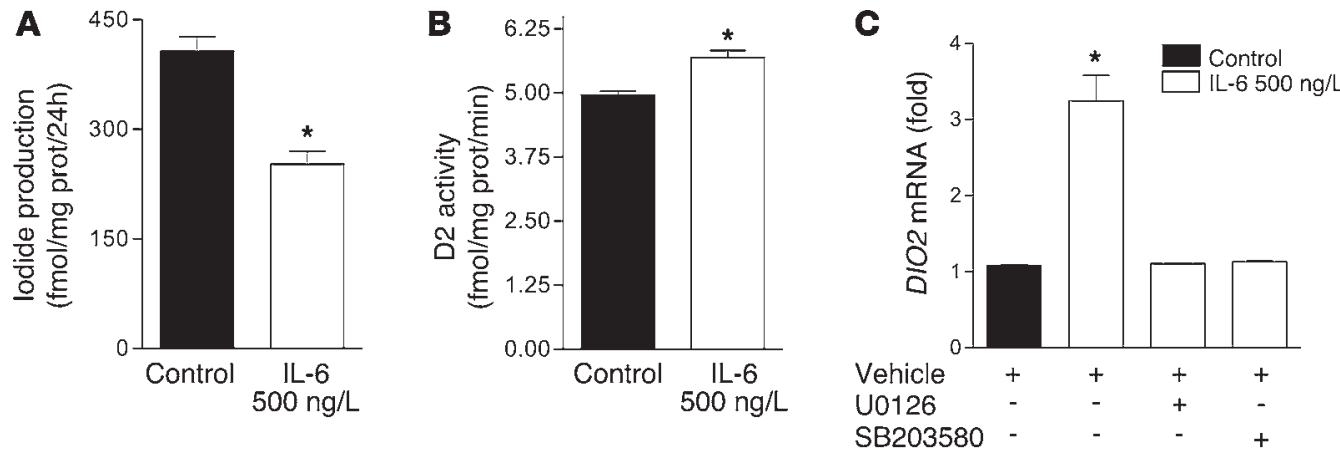

Figure 2

Changes elicited by IL-6 in cells expressing endogenous D2. IL-6 decreased D2-catalyzed T4-to-T 3 conversion in MSTO-211 cells (A), whereas it enhanced D2 maximal velocity in the DTT-stimulated assay in cell sonicates (B). The IL-6-induced increase in D2 protein was paralleled by an increase in its respective mRNA, which was blocked by preincubation with MAPK cascade inhibitors U0126 (ERK pathway) and SB203580 (p38 pathway) (C). DIO2 mRNA levels of control cells were set as 1 . Data are mean \pm SD of at least 3 independent experiments. ${ }^{*} P<0.001$ versus control.

$\mathrm{FT}_{4}$ concentration (2 pmol/l). Again, D2 activity was not changed at IL- 6 concentrations of 5 or $25 \mathrm{ng} / \mathrm{l}$, but a significant decrease was observed at $500 \mathrm{ng} / \mathrm{l}$ (Figure 1D), which indicates that IL-6-induced $\mathrm{D} 2$ inhibition is unaffected by low $\mathrm{FT}_{4}$ levels. Since $\mathrm{rT}_{3}$ is known to downregulate D2 activity at a posttranscriptional level and is elevated in NTIS patients, we tested whether $\mathrm{rT}_{3}$ also interferes with D2 activity. Levels of $\mathrm{rT}_{3}$ observed in critically ill patients $(1.18 \mathrm{nmol} / \mathrm{l})$ did not change enzyme activity (Figure 1E). Remarkably, in contrast to the significant decrease of D2-catalyzed deiodination by intact cells, $500 \mathrm{ng} / 1$ IL- 6 caused a significant increase in DTT-stimulated D2 activity in cell sonicates (Figure 1F), which indicates that $V_{\max }$ of D2 increased despite the reduced deiodination by intact cells.

Deiodination rates in cells expressing endogenous D2. To determine whether endogenous human D2 under control of its homologous promoter would show the same characteristics as those found in HEK-293 cells transiently expressing recombinant D2, we performed similar experiments using MSTO-211 human mesothelioma and TT human medullary carcinoma cell lines, both of which express D2 (28, 29). Similar to the results obtained in intact HEK- 293 cells, $T_{3}$ production by MSTO-211 cells was diminished in the presence of $500 \mathrm{ng} / 1$ IL-6, whereas in sonicates, D2 activity increased (Figure 2, A and B). Identical results were obtained in TT cells (data not shown).
We also evaluated the effect of IL- 6 on DIO2 mRNA levels to determine the cause of the increase in D2 protein. IL- 6 induced a marked increase in DIO2 mRNA (Figure 2C), which indicates that it stimulated D2 expression at a transcriptional level. To determine which transduction pathways were involved in activation of the DIO2 gene, MSTO-211 cells were pretreated for 20 minutes with $5 \mu \mathrm{M}$ of the MAPK inhibitors U0126 or SB203580 before IL- 6 addition. At the $5 \mu \mathrm{M}$ concentration, U0126 acts by inhibiting the MAPK cascade, preventing the activation of ERK and its pathways, whereas SB203580 directly inhibits the p38 MAPK pathway (30). These actions are specific at these concentrations and do not affect other MAPK cascades. We observed that both U0126 and SB203580 blocked DIO2 mRNA induction by IL-6 (Figure 2C).

$N$-acetyl-L-cysteine (NAC) prevents the effects of IL-6 on D2-mediated deiodination, but not the IL-6-induced increase of DIO2 mRNA. Since the increased D2 activity in cell sonicates was paralleled by increased DIO2 mRNA levels, we speculated that the decrease in $\mathrm{D} 2$ deiodination by the intact cells in culture could be caused by generation of ROS and resultant oxidative stress $(31,32)$. Initially, we evaluated 30 -minute pretreatment with $2 \mathrm{mM} \mathrm{NAC}$, an antioxidant that increases intracellular GSH. Interestingly, the inhibitory effect of $500 \mathrm{ng} / \mathrm{l}$ IL-6 on D2-mediated deiodination was
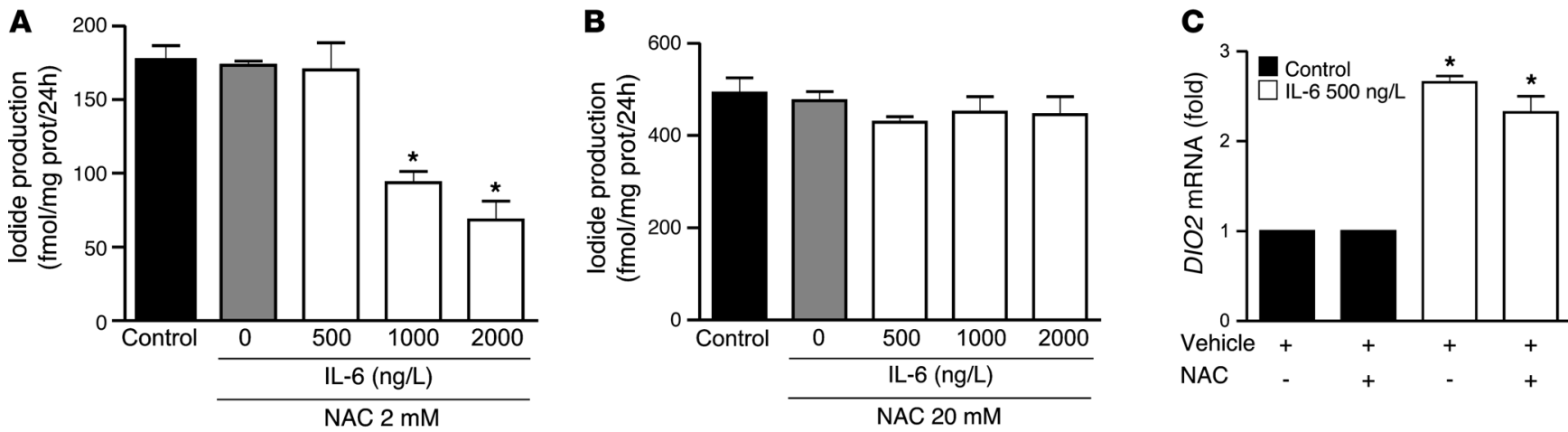

Figure 3

NAC abolishes the inhibitory effect of IL-6 on D2-mediated T 3 production in MSTO-211 cells in a dose-dependent manner. 2 mM NAC abolished the effect of $500 \mathrm{ng} / \mathrm{IL}-6(\mathbf{A})$, but higher amounts of NAC (20 mM; B) were necessary to overcome the effect of 1,000 and 2,000 ng/l IL-6. IL-6 induced DIO2 mRNA, and this effect was not blocked by $2 \mathrm{mM} \mathrm{NAC} \mathrm{(C).} \mathrm{DIO2} \mathrm{mRNA} \mathrm{levels} \mathrm{of} \mathrm{control} \mathrm{cells} \mathrm{were} \mathrm{set} \mathrm{as} 1$. Data are mean \pm SD of at least 3 independent experiments. ${ }^{*} P<0.0001$ versus control. 

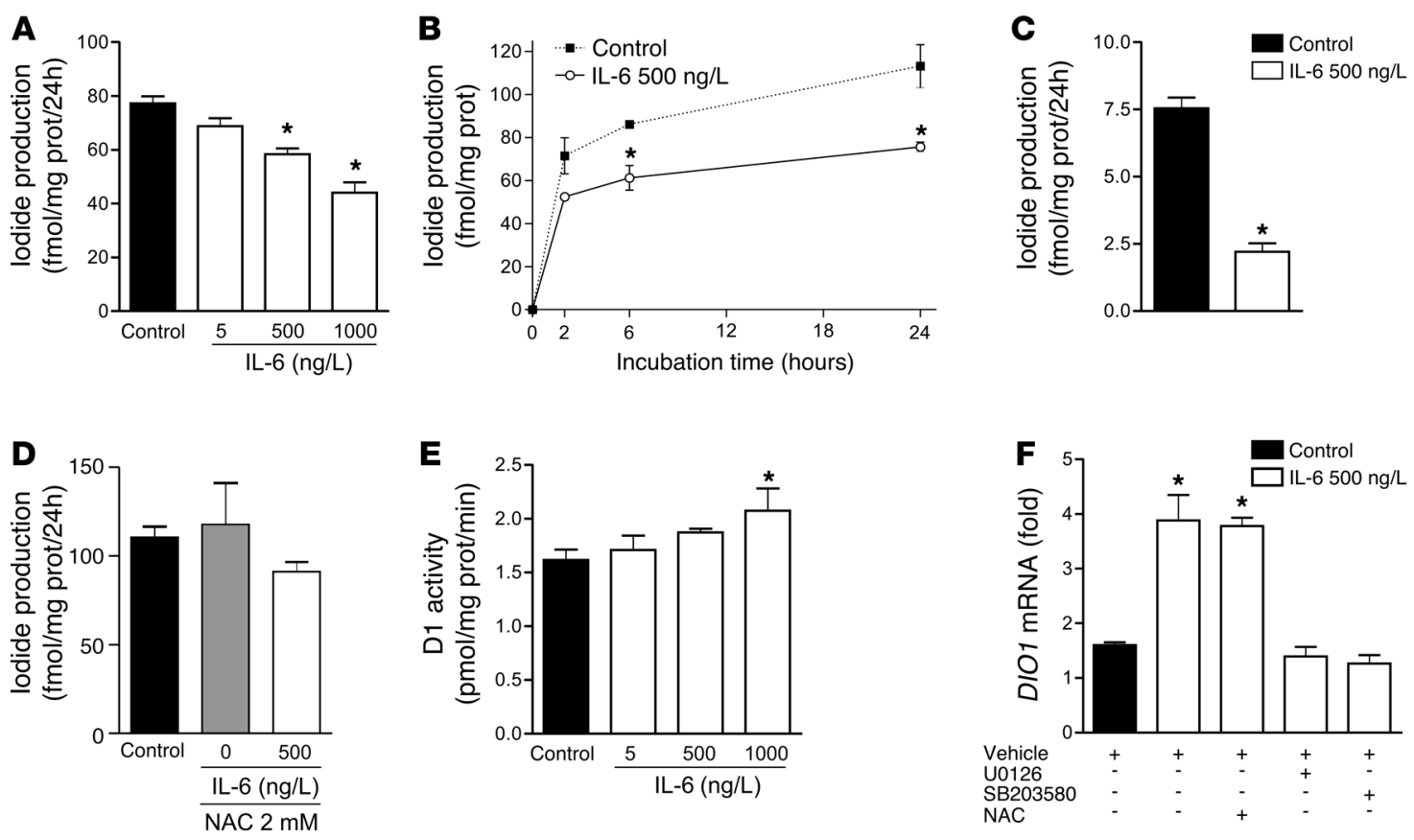

\section{Figure 4}

IL-6 decreases D1-catalyzed T4-to- $T_{3}$ conversion in HepG2 cells. IL-6 inhibition of D1-catalyzed $\mathrm{T}_{3}$ production in intact cells was dose-dependent (A) and already observed after 2 hours of incubation (B). The effect of IL- 6 was not altered by low $\mathrm{FT}_{4}$ levels $(2 \mathrm{pM} ; \mathbf{C})$ and was abolished by the addition of 2 mM NAC to culture media (D). In contrast, IL-6 stimulated D1 activity in the DTT-stimulated assay in HepG2 cell sonicate (E). DIO1 mRNA levels in HepG2 cells were induced by IL-6, and this effect was blocked by U0126 or SB203580, but not by 2 mM NAC (F). DIO1 mRNA levels of control cells were set as 1 . Data are mean \pm SD of at least 3 independent experiments. ${ }^{*} P<0.001$ versus control.

abolished by addition of 2 mM NAC, but D2 decreases at higher cytokine concentrations were maintained (Figure 3A). In this case, pretreatment with $20 \mathrm{mM}$ NAC completely blocked even the effects of higher concentrations of IL- 6 on cellular D2 deiodination (Figure 3B). However, pretreatment with NAC did not prevent DIO2 mRNA induction by IL-6 (Figure 3C), which indicates this was caused by a ROS-independent effect of the cytokine.

Effect of IL-6 on D1 and D3 action in intact cells and in cell sonicates. We next evaluated the effect of IL- 6 on the D1-mediated $\mathrm{T}_{4}$-to- $\mathrm{T}_{3}$ conversion in HepG2 human hepatocarcinoma cells. The effects of IL- 6 were similar to those found for $\mathrm{D} 2$. D1-mediated $\mathrm{T}_{3}$ production decreased in a dose-dependent manner in intact cells (Figure 4, A and B). The effect of IL- 6 on D1 in intact cells was preserved at low $\mathrm{FT}_{4}$, but was abolished by NAC addition (Figure 4, C and D). Despite this, DTT-mediated catalysis by D1 was modestly increased in sonicates of the same cells (Figure 4E). Moreover, IL- 6 treatment increased DIO1 mRNA, and this effect was abolished by U0126 and SB203580 (Figure 4F).

As mentioned above, increased D3 expression has been previously demonstrated in liver and skeletal muscle of NTIS patients $(3,8-10)$. To determine whether this effect could also be mediated by IL-6, we evaluated human D3 activity using the same model system. Because the concentrations of $\mathrm{T}_{3}$ deiodination products in the media were too low to be accurately measured by paper chromatography, Sephadex LH-20 chromatography was used to quantify $\left[{ }^{125} \mathrm{I}\right] \mathrm{T}_{2}$ and $\left[{ }^{125} \mathrm{I}\right] \mathrm{T}_{1}$. We used a slightly modified validated method that uses stepwise elution by successive application of increasing ethanol concentrations to separate ${ }^{125} \mathrm{I}^{-},\left[{ }^{125} \mathrm{I}\right] \mathrm{T}_{1}$, and $\left[{ }^{125} \mathrm{I}\right] \mathrm{T}_{2}(33,34)$. As shown in Figure 5A, using identical amounts of the same cell protein $(100 \mu \mathrm{g})$, the pattern of separation of the deiodination products obtained with column elution fractions showed excellent correlation with paper chromatography.

IL- 6 caused a significant increase in D3 activity during incubation with intact MCF-7 human breast carcinoma cells in a dose- and time-dependent fashion (Figure 5, B and C); this was prevented by 30 minutes of preincubation with NAC (Figure 5D). IL-6 also increased DTT-stimulated D3 sonicate activity (Figure 5E), which was paralleled by an increase in DIO3 mRNA. This putative transcriptional effect was abolished by 20 minutes of preincubation with $5 \mu \mathrm{M}$ U0126 or SB203580, but not by 2 mM NAC (Figure 5F).

IL-6 induces ROS in cultured buman cells. We next measured the amount of intracellular ROS generated by IL-6 in cultured HEK-293, MSTO-211, HepG2, and MCF-7 cells. All cell lines were preincubated for 30 minutes with 5-(and 6)-chloromethyl-2'7'-dichlorodihydrofluorescein diacetate (CM-H2-DCFDA) and then treated with increasing levels of IL-6. As a positive control, we used $\mathrm{H}_{2} \mathrm{O}_{2}(100 \mu \mathrm{M})$, commonly used as an inducer of oxidative stress in cultured cells and in other systems. Addition of 500, 1,000, or 2,000 ng/l IL-6 to culture media significantly increased intracellular ROS in all cell lines in a dose-dependent fashion (Figure 6). The most prominent effect was observed in MSTO-211 cells; MCF-7 cells exhibited a lesser, but still significant, response. This variation may reflect differences in the response to oxidative insult in different cell lines (35).

We also evaluated whether the effects of $\mathrm{H}_{2} \mathrm{O}_{2}$ on D1, D2, and D3 deiodination would be similar to those observed with IL-6. Adding 15-60 $\mu \mathrm{M} \mathrm{H}_{2} \mathrm{O}_{2}$ to cell media replicated the IL-6-induced decrease in $\mathrm{D} 1$ and D2 deiodination, and this was prevented by $30 \mathrm{~min}-$ utes of pretreatment with $2 \mathrm{mM}$ NAC (Figure 7, A, B, D, and E). 

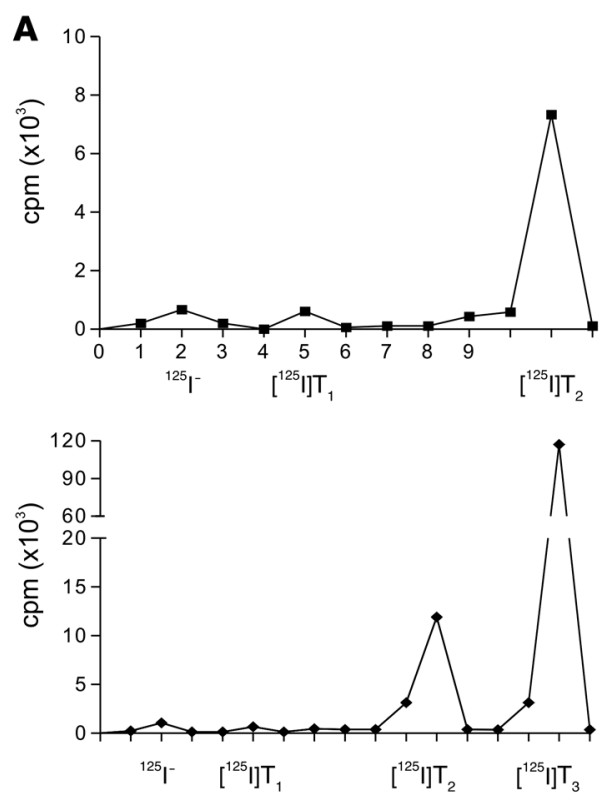
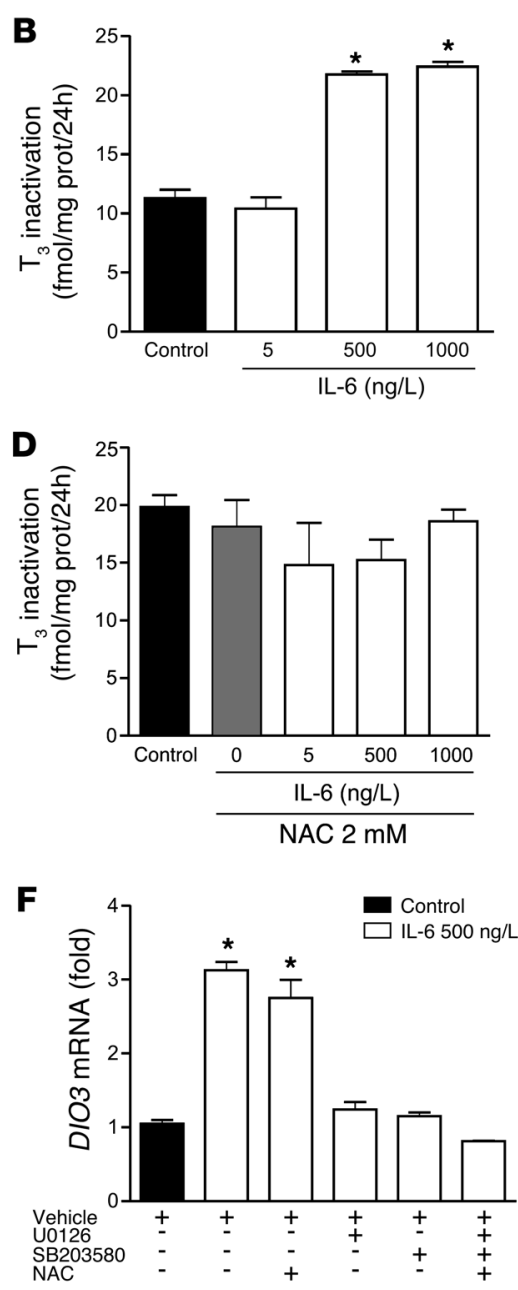
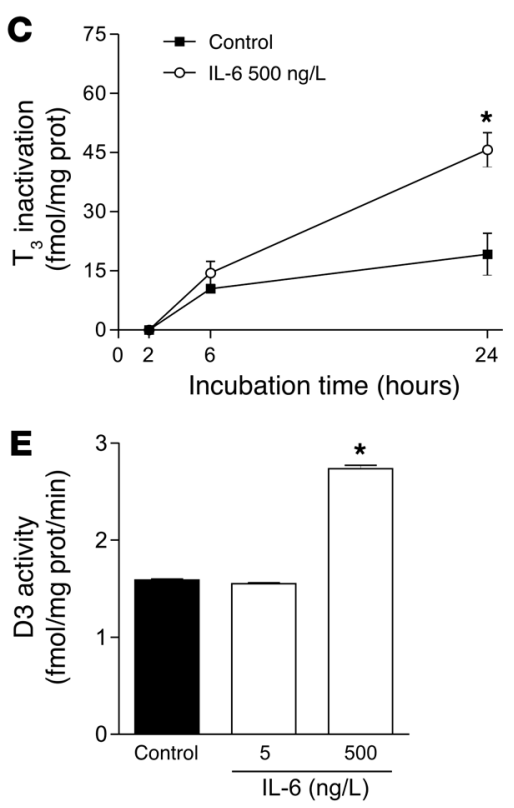

Figure 5

IL-6 induces D3 expression in MCF-7 cells. (A) Chromatographic patterns of the products of D3-mediated $\mathrm{T}_{3}$ deiodination, determined by Sephadex LH-20 columns (top) or paper chromatography (bottom). IL-6 augmented intact cell $\mathrm{T}_{3}$ inactivation by D3 in a dose- and time-dependent fashion (B and C). D3 activity returned to control levels in the presence of NAC (D). D3 activity in cell sonicates and DIO3 mRNA levels were induced in the presence of $500 \mathrm{ng} / \mathrm{IL}-6$ (E and F). The effect of IL-6 on DIO3 mRNA levels was blocked by U0126 and SB203580, but not by 2 mM NAC. DIO3 mRNA levels of control cells were set as 1 . Data are mean \pm SD of at least 3 independent experiments. ${ }^{*} P<0.001$ versus control.

$\mathrm{H}_{2} \mathrm{O}_{2}$ treatment elicited an increase in DIO1 and DIO2 mRNA levels, which was abolished by U0126 and SB203580 (Figure 7, $\mathrm{C}$ and F). However, in contrast to what we observed with IL-6, $\mathrm{H}_{2} \mathrm{O}_{2}$ induction of deiodinase mRNA levels was prevented by the presence of NAC. These findings indicate that ROS-mediated MAPK activation also stimulates deiodinase gene transcription.

In contrast, an $\mathrm{H}_{2} \mathrm{O}_{2}$-induced increase in $\mathrm{D} 3$-mediated $\mathrm{T}_{3}$ inactivation was already apparent at $15 \mu \mathrm{M}$ (Figure 7G). Similarly, this $\mathrm{H}_{2} \mathrm{O}_{2}$ effect was abolished by 30 minutes of pretreatment with $2 \mathrm{mM}$ NAC (Figure $7 \mathrm{H}$ ). $\mathrm{H}_{2} \mathrm{O}_{2}$ incubation also increased DIO3 mRNA levels as a result of MAPK pathway activation (Figure 7I).

IL-6 reduces intracellular, but not extracellular, GSH. It was puzzling that IL-6 increased endogenous D3 activity in intact cells in parallel with D3 protein (and DIO3 mRNA), whereas D1 and D2-mediated catalysis by intact cells was reduced under similar conditions. These apparently conflicting results could be explained by variations in the response of different human cell lines to the induction of oxidative stress or differences in the response of the deiodinases to such effects. Confocal microscopy studies have identified D2 in the endoplasmic reticulum with the carboxy terminus in the cytosol, whereas D1 and D3 are located in the plasma membrane, with the active center of D1 also predicted to be in the cytosolic compartment (36-38). The location of D3 is less clear. Like D1 (but not D2), D3 can be labeled by covalent cell-impermeant alkylating agents such as sulfo-biotin. Since IL-6 alters GSH/oxidized GSH (GSH/ GSSG) shuttling and recycling, leading to intracellular GSH depletion as a result of ROS formation $(39,40)$, extracellular location of the catalytic portion of D3 might give it access to extracellular GSH (or other cofactor substitutes), which would explain why decreased intracellular GSH is not a rate-limiting factor for D3 function.

To examine these issues, we measured extracellular and intracellular GSH after IL-6 treatment. Addition of 500 or $1,000 \mathrm{ng} / 1$ IL- 6 to culture media modestly, but significantly, decreased extracellular GSH in incubations with HEK-293 cells, but not with HepG2, MSTO-211, or MCF-7 cells (Figure 8A). Conversely, IL-6 induced a dose-dependent decrease in intracellular GSH levels in all cell lines, mirroring the results obtained for intracellular ROS measurements (Figure 6 and Figure 8A). 

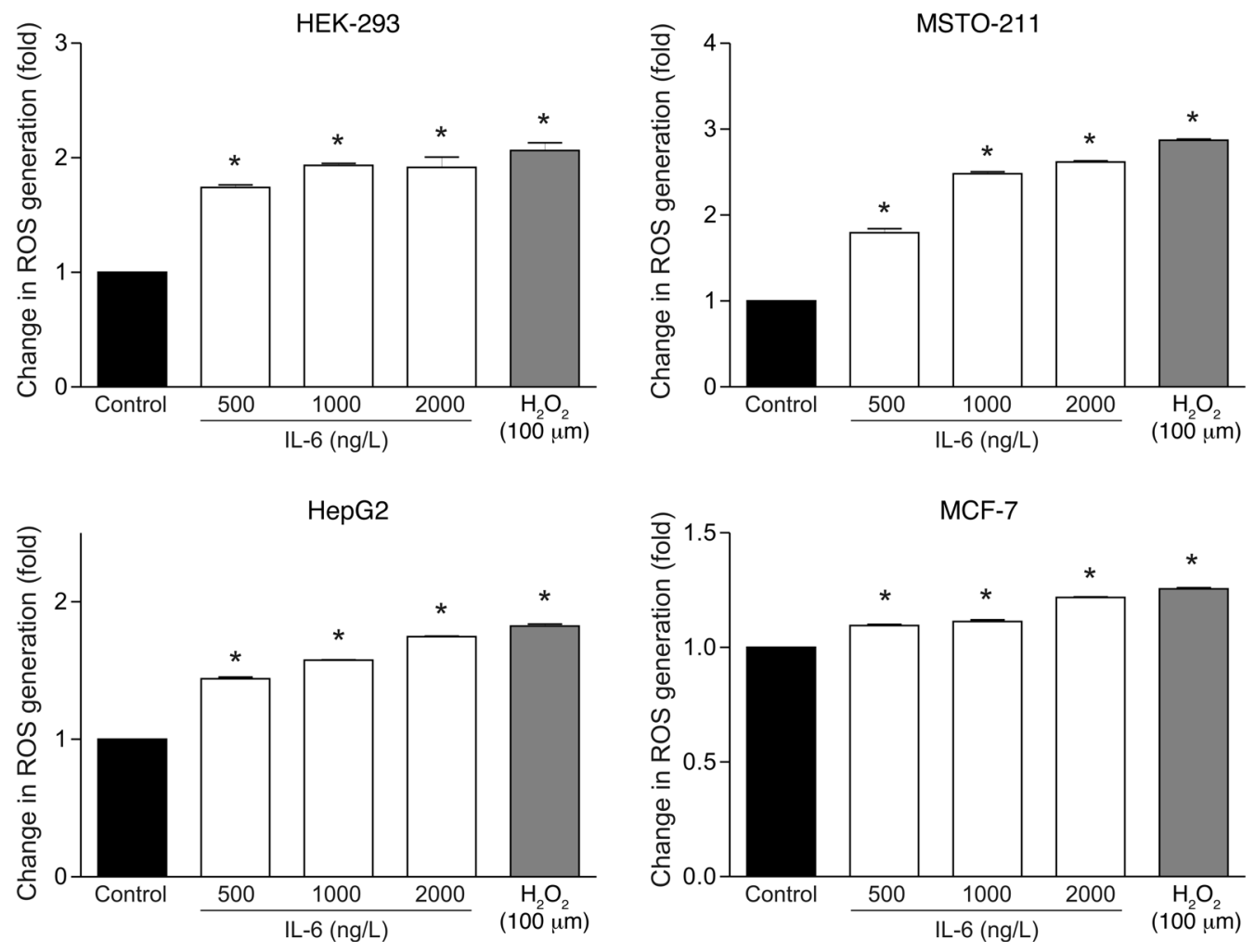

\section{Figure 6}

IL-6 induces ROS generation in HEK-293, MSTO-211, HepG2, and MCF-7 cell lines in a dose-dependent fashion. Cells were stained with $5 \mu \mathrm{M}$ CM-H2-DCFDA and analyzed by fluorescence emission. Graphs express the normalized fluorescence intensity versus basal level. ${ }^{\star} P=0.01$ versus control.

To investigate whether the D3-specific cellular localization could explain its positive response to IL-6, we evaluated transiently expressed D1, D2, and D3 in intact HEK-293 cells in the presence or absence of $4 \mathrm{mM} \mathrm{GSH}$, taking advantage of the fact that GSH does not cross the plasma membrane (41). As expected, $500 \mathrm{ng} / \mathrm{l}$ IL- 6 caused a decrease in D1 and D2 activities, and this was not prevented by extracellular GSH (Figure 8B). However, in contrast to the results obtained in intact cells expressing endogenous D3 (MCF-7 cells; Figure 5A), D3 activity transiently expressed in intact HEK-293 cells was decreased by IL-6 in a dose-dependent fashion. Addition of $4 \mathrm{mM} \mathrm{GSH}$ to the culture media restored D3 activity to control levels (Figure 8, B and C), which suggests that portions of D3 critical for its function are accessible to extracellular GSH and that this can overcome the adverse effects of intracellular thiol deficiency on D3 function.

\section{Discussion}

In vivo studies of illness and of IL- 6 infusion, while showing that $\mathrm{T}_{4}$ and $\mathrm{T}_{3}$ metabolism is rapidly perturbed, do not tell us which deiodinases are affected, how they are altered, or what is the mechanism. Without exception, all studies of the deiodinases in sick humans or animals have measured only the $V_{\max }$ of the enzymes (equivalent to the level of the protein), not their in vivo function. It is not possible to estimate this other than by speculating about what might be happening based on decreased $\mathrm{T}_{3}$ and increased $r \mathrm{~T}_{3}$. These changes are ambiguous as indicators of in vivo deiodinase function, since they can be caused by reduced D1 (and D2), increased D3, or both.
Using intact human cells in culture systems that mimic the physiological actions of the endogenous deiodinase cofactor(s) and $\mathrm{FT}_{4}$, we demonstrated here that IL- 6 inhibited $\mathrm{T}_{3}$ production by recombinant or endogenous D1 and D2 (Figures 1-4). Surprisingly, however, the quantities of both D1 and D2 in sonicates of the same cells as assayed in the presence of DTT were simultaneously increased. The increases in D1 and D2 proteins were paralleled by an increase in the respective mRNAs for both enzymes. Thus, IL-6 blocks the catalytic activity of increased amounts of D1 and D2, possibly by interfering with the effects of endogenous cofactors. Addition to the culture medium of NAC, an antioxidant that increases intracellular GSH levels, completely prevented the inhibitory effect of IL- 6 on D1- and D2-mediated $\mathrm{T}_{4}$-to- $\mathrm{T}_{3}$ conversion. This was consistent with the hypothesis that IL-6 inhibits the function of endogenous D1 and D2 by increasing cellular ROS, thereby reducing GSH, or a GSH-dependent endogenous cofactor for D1 and D2 (Figures 6 and 8). In contrast, IL-6 stimulated endogenous D3-mediated inactivation of $\mathrm{T}_{3}$ by intact MCF-7 cells, accurately reflecting the increase in cell sonicate D3 (and its mRNA). Taken together, these results suggest that IL-6-induced oxidative stress impairs D1 and D2 function while augmenting that of $\mathrm{D} 3$, consequently reducing $\mathrm{T}_{3}$ production and accelerating its inactivation as well as converting $\mathrm{T}_{4}$ to $\mathrm{rT}_{3}$, mimicking the events in critically ill patients. This hypothesis is supported by the identical effects of $\mathrm{H}_{2} \mathrm{O}_{2}$ (Figure 7). Our results also imply major differences between the functional response of D1 and D2 - as opposed to that of D3 - to oxidative stress, as discussed below. 
D1
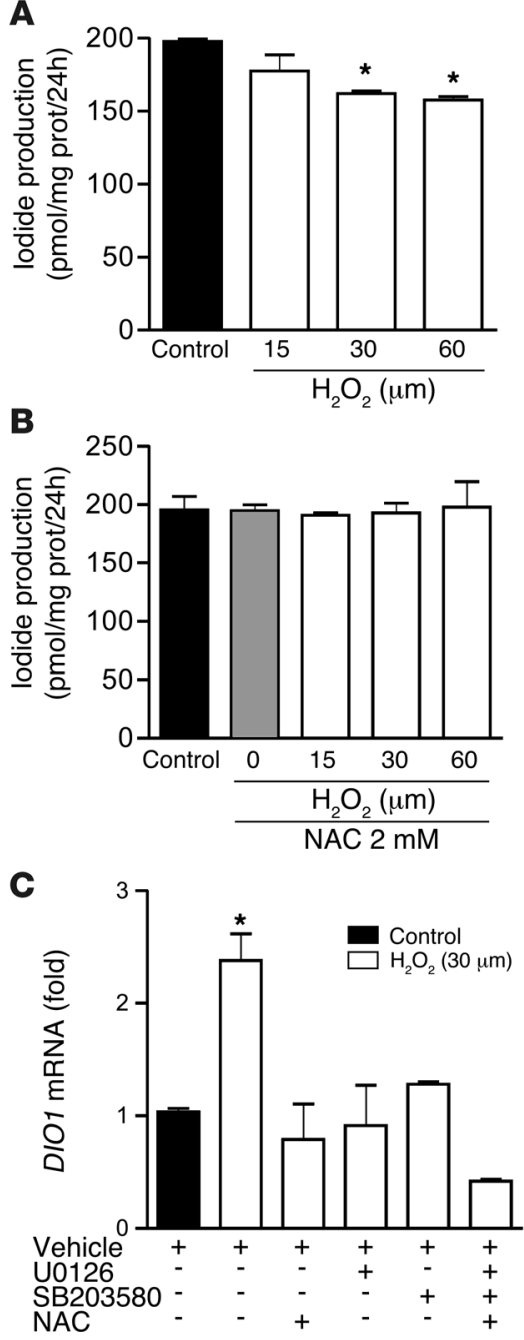

D2

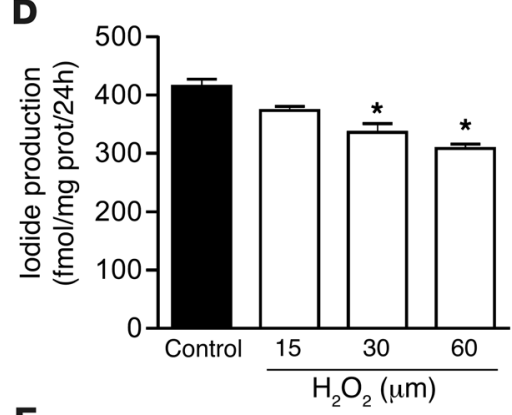

E

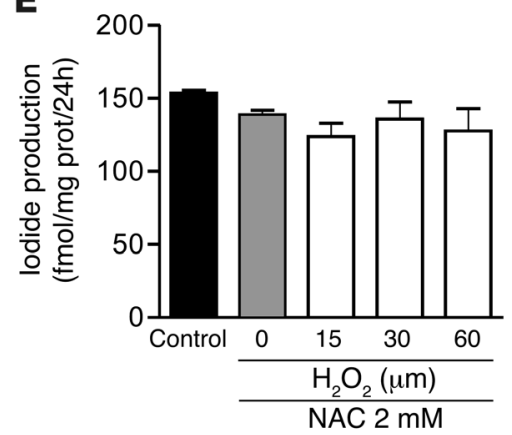

F

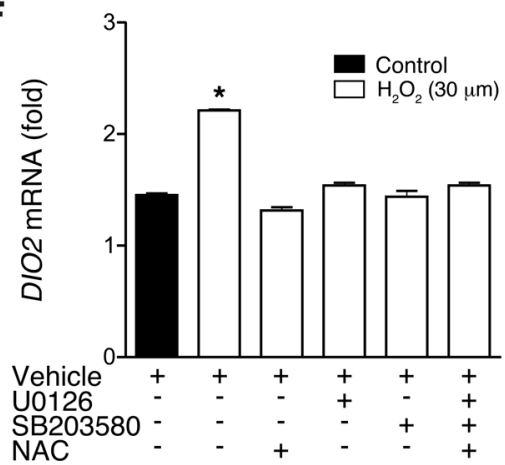

D3

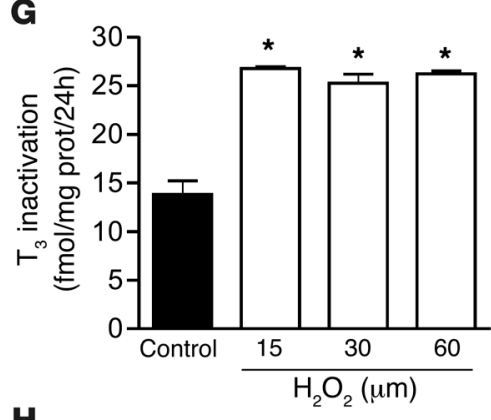

H
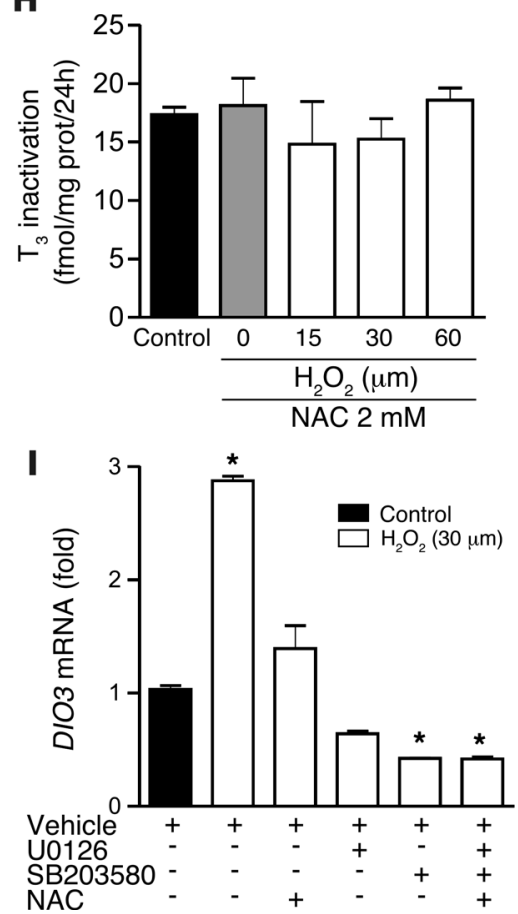

Figure 7

$\mathrm{H}_{2} \mathrm{O}_{2}$ mimics the effects of IL-6 on D1, D2, and D3 deiodination in intact cells. $\mathrm{H}_{2} \mathrm{O}_{2}$ decreased D1 (HepG2; A) and D2 (MSTO-211; D) and enhanced D3 (MCF-7; G) activities, as measured in intact cells, in a dose-dependent fashion; its effect was abolished in the presence of 2 mM NAC (B, E, and H). $\mathrm{H}_{2} \mathrm{O}_{2}$ induced DIO1, DIO2, and DIO3 mRNA levels, and this effect was blocked by U0126 and SB203580 and by 2 mM NAC (C, F, and I). DIO1, DIO2, and DIO3 mRNA levels of control cells were set as 1 . Data are mean \pm SD of at least 3 independent experiments. ${ }^{\star} P<0.0001$ versus control.

Oxidative stress, caused by augmented ROS or reactive nitrogen species (RNS) generation, is characteristic of many diseases that are associated with NTIS. Patients usually have reduced plasma and intracellular levels of antioxidant scavenging molecules, including GSH, as well as decreased activity of the antioxidant enzymatic system involved in ROS detoxification (41-43). The increased production of proinflammatory cytokines such as IL-6, a typical feature in NTIS, has been implicated in this process, since it leads to a significant increase in superoxide radical production through the enzyme complex of the NADPH oxidase pathway (40). The augmented reactive species in turn depletes intracellular GSH, decreasing the GSH/GSSG ratio $(31,40,44)$.

Changes in the intracellular redox state can decrease deiodinase function by independent mechanisms. When ROS is increased, it is likely that the putative thiol cofactors required for these enzymes are depleted, thus impairing reactions that require a reductive intracellular environment. Moreover, increased ROS generation can lead to protein modifications (e.g., oxidation of cysteinyl sulfhydryl groups) which in turn can affect protein function $(45,46)$. Upon oxidation, the cysteine residues within proteins can be modified to different products, including reversible inter- or intramolecular disulfide bonds and GSH-mixed disulfides. This might be particularly relevant for deiodinase function $(47,48)$. Moreover, recent studies have demonstrated that selenocysteine incorporation is reduced substantially after treatment of cells with agents that cause oxidative stress as a result of nuclear sequestration of SECIS-binding protein 2 , which, under such conditions, may represent a mechanism to regulate the expression of selenoproteins $(45,47)$. In fact, deiodinase translation seems inhibited since, in all of the experiments, the increase in sonicate $V_{\max }$ was less pronounced 
A
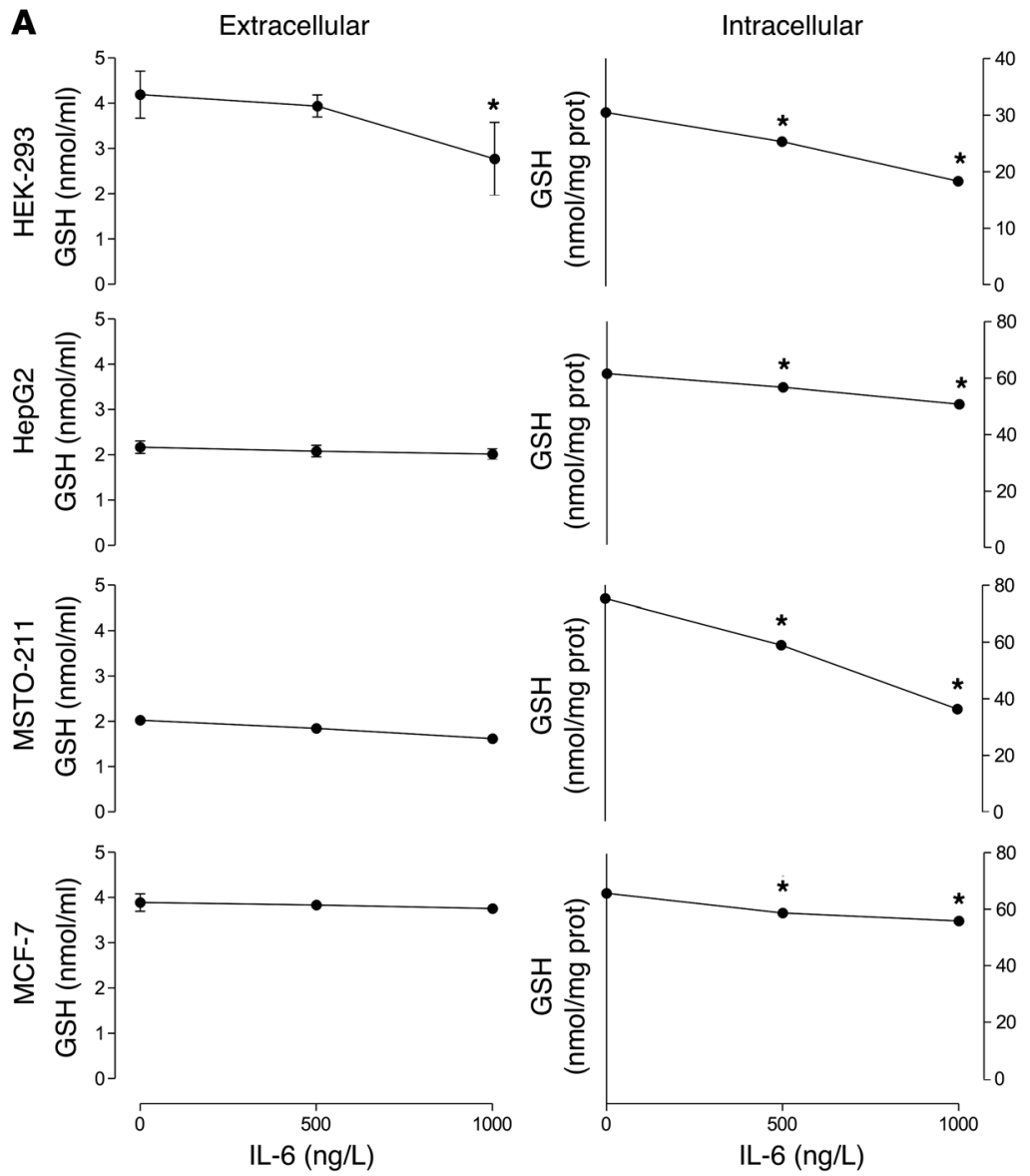
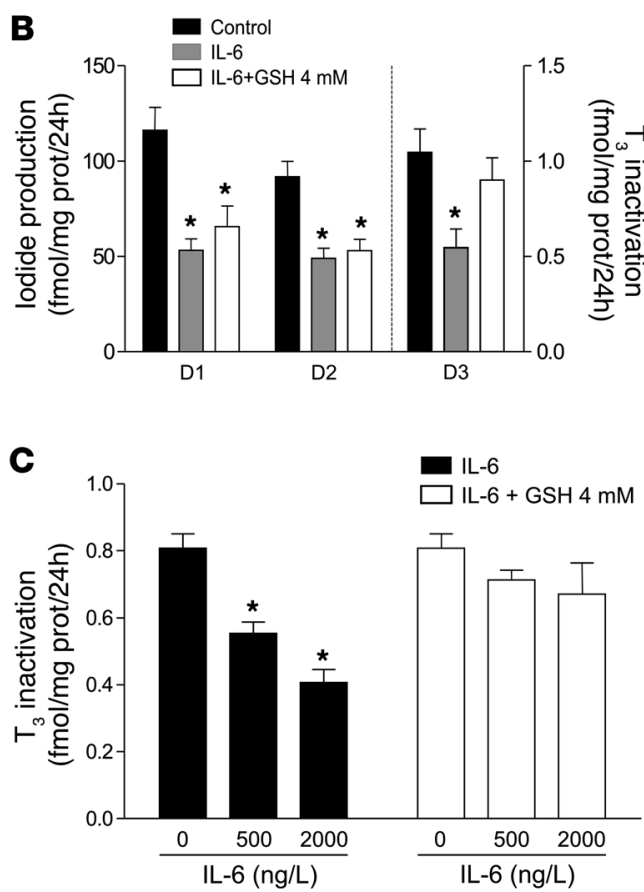

Figure 8

IL-6 reduces intracellular GSH levels in HEK-293, HepG2, MSTO-211, and MCF-7 cell lines. (A) Effect of IL-6 on intracellular and extracellular GSH levels in various cell lines. (B) GSH (4 mM) prevented inhibition of intact cell D3 activity, but not that of D1 or D2, in HEK-293 cells transiently expressing these enzymes. (C) The effect of IL-6 in HEK-293 cells transiently expressing D3 was dose dependent and blocked in the presence of $4 \mathrm{mM} \mathrm{GSH}$. Data are mean \pm SD of at least 3 independent experiments. ${ }^{*} P=0.001$ versus control.

than that of the respective mRNA. Of course, this effect could well affect other enzymes, such as thioredoxin reductase or the GSH peroxidases, which are important components of the redox defense system.

In contrast to the impairment of D1 and D2 function we observed in intact cells, IL- 6 induced an increase of both transiently expressed and endogenous D1 and D2 in cell sonicates (Figures 1,2 , and 4), as measured in the presence of the potent thiol cofactor DTT. Although this seems paradoxical, it can be explained by the fact that DTT negates effects of any deficiency in endogenous cofactor and could as well reverse the adverse effects of cysteinyl sulfhydryl oxidation on enzyme function. For example, exposure of D2-expressing cells to diamide, which depletes GSH, inactivates the enzyme, whereas addition of DTT rapidly regenerates its function (49). Thus, measurements of D1 and D2 activities in cell sonicates under ideal conditions, namely with an excess of artificial enzyme cofactor (DTT) and substrate, does not necessarily reflect the physiological intracellular ambient conditions that are better reproduced by intact cell assays. Accordingly, it has been recently demonstrated that the potent thiol DTT alters the in vivo catalytic properties of the D2 enzyme (16). It is likely that results obtained from all sonicate assays with high DTT mask not only a deficiency of endogenous cofactors, but also potential oxidative damage to the deiodinase proteins, jeopardizing conclusions regarding deiodination function in vivo during illness.

Consistent with the increase in deiodinase activities in DTTcatalyzed sonicate assays, we observed an IL-6-elicited increase in all 3 deiodinase mRNAs that involved the p38 MAPK and ERK pathways. Stimulation of the IL- 6 signaling pathway occurs via the IL-6 receptor/gp130 receptor and initiates IL- 6 signal transduction. Ligand binding to the IL- 6 receptor followed by the assembly of the receptor complex leads to initiation of the JAK/STAT pathway as well as to MAPK and ERK cascade activation (50-52). The activation of these MAPK cascades activates cAMP response element-binding protein (CREB), a known inducer of Dio1, Dio2, and Dio3 gene transcription (30, 53-55). Of note, CREB is involved in the oxidative stress response, a newly recognized concept that may be implicated in several pathological events (53). The effects of oxidative stress on deiodinase expression were further confirmed by exposing the cells to $\mathrm{H}_{2} \mathrm{O}_{2}$, a commonly used ROS. Similar to IL-6, $\mathrm{H}_{2} \mathrm{O}_{2}$ induced a dose-dependent decrease in D1 and D2 while increasing D3 activities (Figure 7). $\mathrm{H}_{2} \mathrm{O}_{2}$ also increased deiodinase mRNAs by a mechanism that involved MAPK activation (Figure 7). 


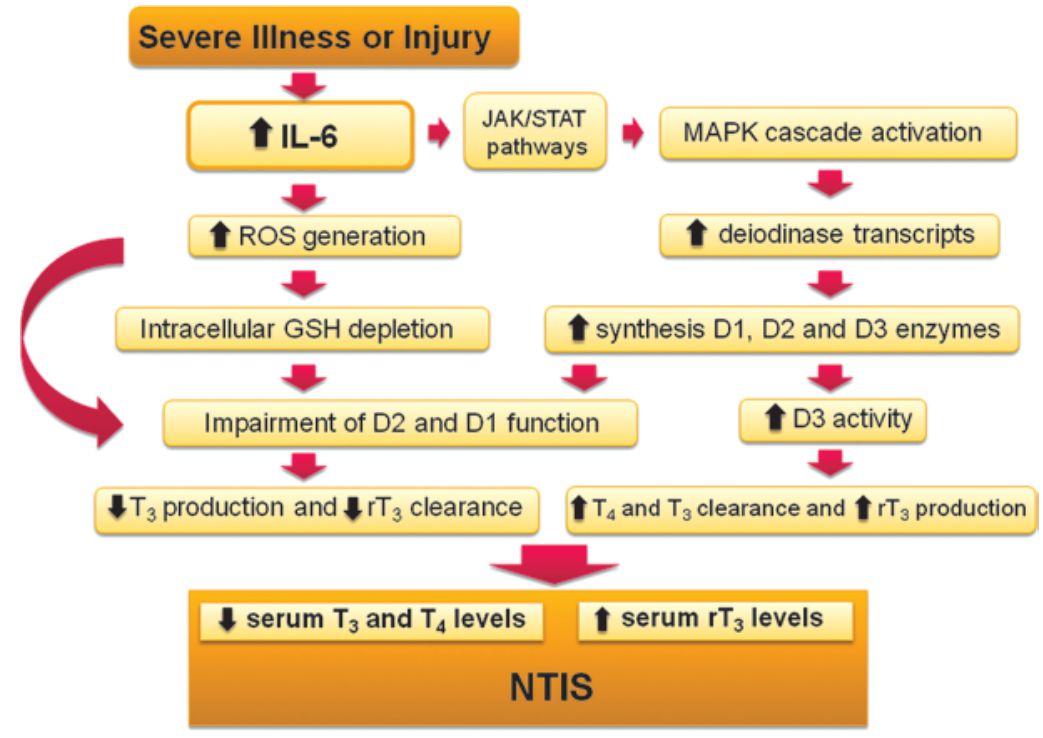

Figure 9

Proposed mechanism for the effects of IL-6 resulting in NTIS.

The system developed in these experiments allowed us to evaluate, for the first time to our knowledge, the effect of IL- 6 on deiodinases under conditions observed in vivo in the early phase of NTIS and to show that IL- 6 replicated the in vivo effects of illness on thyroid activation and inactivation in human cells expressing endogenous deiodinases. It did so despite an IL-6-induced increase in the enzyme levels by increasing ROS, which seems logical since we know that a thiol cofactor is required to support catalysis by the deiodinases.

Consistent with clinical studies showing that serum $\mathrm{T}_{3}$ concentrations are the first parameter to change and the last to recover $(1$, $2,7)$, the effect of IL- 6 was already apparent within a 2-hour exposure of the cells to this cytokine (Figure 1C and Figure 4B) and was prevented by the potent antioxidant NAC (Figure 4, B and C), which increases intracellular GSH synthesis. It is unlikely that the acute decrease in serum $T_{3}$ is caused by a decrease in D1 protein, given the relatively long half-life of human D1 protein ( $\sim 12$ hours; ref. 56); this is supported by previous studies in animal models that suggest that the decrease in $\mathrm{T}_{3}$ levels precedes the decrease in Dio1 mRNA and activity (57). Moreover, increased D3 expression was previously demonstrated in the liver and muscle of sick patients $(3,8-10)$ and in the hearts of rats subjected to myocardial infarction, proposed as a model of NTIS (58).

The effect of IL- 6 on deiodinase mRNAs was consistent with studies demonstrating increases in Dio2 mRNA and activity during the acute phase of chronic inflammation, probably due to activation of the cAMP pathway (59). On the other hand, oxidative stress induced by $\mathrm{H}_{2} \mathrm{O}_{2}$ increases Dio2 and Dio3 gene transcription and D3 activity in cultured rat astrocytes (30), whereas pretreatment with an antioxidant prevents the increase in Dio3 mRNA levels in rats with pathological ventricular hypertrophy (60), which suggests that oxidative stress is involved in these processes.

Nonetheless, since all 3 deiodinases are selenocysteine-containing, thiol-interacting oxireductases, it was expected that these enzymes would be equally sensitive to the redox alterations. Thus, why was the increase in D3 protein reflected by an increase in D3 function, but the increases in D1 and D2 proteins were not? The extracellular location of a portion of D3, a characteristic not shared by D1 and D2, could allow its access to extracellular GSH, possibly explaining why a decrease in intracellular GSH is not rate limiting for D3 function, but is for D1 and D2. This is in accordance with our results in HEK-293 cells demonstrating that, although IL-6 induced a decrease in the function of all 3 transiently expressed deiodinases, only D3 function was restored by the addition of GSH to the culture media (Figure 8, B and C). This presumption is reinforced by the fact that GSH does not readily cross the cell membrane $(41,61)$ and is consistent with earlier cell-biological studies mentioned above (36-38). Therefore, it seems possible that D3 is protected by extracellular GSH during the process of D3 endosomal internalization or that its active center is facing outward, thus explaining why its activity in intact cells parallels the D3 activity in sonicates of the same cells.

In conclusion, our findings demonstrated that pathophysiologically relevant concentrations of IL- 6 reduce D1 and D2 function and increase that of D3, providing a single mechanistic explanation for the decreased serum $\mathrm{T}_{3}$ and increased $\mathrm{rT}_{3}$ observed in the acute phase of NTIS (Figure 9). The decrease in D1 will both reduce plasma $T_{3}$ production and impair $\mathrm{rT}_{3}$ deiodination, while the decrease in D2 will supplement this by impairing intracellular $\mathrm{T}_{4}$-to- $\mathrm{T}_{3}$ conversion. On the other hand, the increased D3 protein, which has its function preserved by its more ready access to GSH (or other extracellular reducing agents), will further decrease plasma $T_{3}$ and increase the production of $\mathrm{rT}_{3}$ from $\mathrm{T}_{4}$. The general increase in the cellular deiodinase proteins is caused by a combination of IL-6-induced ROS (also found with $\mathrm{H}_{2} \mathrm{O}_{2}$ ) and specific activation of JAK/STAT pathways by this cytokine. Although other factors in sick patients may also contribute to NTIS, these observations and unifying hypothesis represent a major step forward in unraveling this longstanding enigma, leading to what we believe to be a previously unrecognized combinatorial pathway that may be viewed largely as a general response to oxidative stress. Our results therefore suggest that rather than a protective or a maladaptive 
process, the changes in plasma $\mathrm{T}_{4}, \mathrm{~T}_{3}$, and $\mathrm{rT}_{3}$ are a consequence of cellular stress. Whether antioxidants, such as NAC, could be beneficial as an adjuvant therapy together with other therapeutic measures in critically ill patients remains to be evaluated.

\section{Methods}

Reagents. Reagents were from Invitrogen, Calbiochem-Novabiochem, or Sigma-Aldrich. Outer ring-labeled $\left[{ }^{125} \mathrm{I}\right] \mathrm{T}_{3}$ and $\left[{ }^{125} \mathrm{I}\right] \mathrm{T}_{4}$ (specific activity, $4,400 \mathrm{Ci} / \mathrm{mmol}$ ) were from PerkinElmer. Purification of $\left[{ }^{125} \mathrm{I}\right] \mathrm{T}_{4}$ or $\left[{ }^{125} \mathrm{I}\right] \mathrm{T}_{3}$ was performed on LH-20 columns just before it was used to reduce ${ }^{125} \mathrm{I}^{-}$to less than $1 \%$.

Cell culture and condition studies. All experiments performed in these studies were previously approved by the Ethical Committee of the Hospital de Clínicas de Porto Alegre, Porto Alegre, Brazil. HEK-293 cells (human embryonic kidney epithelial cell line; no. CRL 1573), TT cells (human medullary thyroid carcinoma cell line; no. CRL 1803) and MSTO-211H cells (mesothelioma cell line; no. CRL 2081) were obtained from ATCC. MCF-7 cells (mammary carcinoma cell line; no. CR119) and HepG2 cells (hepatocarcinoma cell line; no. CR0294) were obtained from Banco de Células do Rio do Janeiro. HEK-293, MCF-7, and HepG2 cells were grown and maintained in DMEM supplemented with 10\% FBS, whereas MSTO-211 and TT cells were cultured in RPMI medium supplemented with $10 \%$ FBS. Cells were maintained at $37^{\circ} \mathrm{C}$ in a humidified atmosphere of $5 \% \mathrm{CO}_{2}$ and $95 \%$ air, and the culture medium was changed 3 times per week.

In an attempt to reproduce the pathophysiological environment found in control and NTIS patients (10), cells were cultured at variable $\mathrm{rT}_{3}$ concentrations (total $\mathrm{rT}_{3}, 0.3-1.18 \mathrm{nM}$ ) in $1 \mathrm{ml}$ serum-free $0.1 \% \mathrm{BSA}$ (resulting in a free $\mathrm{rT}_{3}$ fraction of $4.9 \% ; 15-59 \mathrm{pM}$ ) (62). The median values of IL- 6 were $2.9 \mathrm{ng} / \mathrm{l}$ (range, $2-21 \mathrm{ng} / \mathrm{l}$ ) in controls and $125 \mathrm{ng} / \mathrm{l}$ (range, $11-8,486 \mathrm{ng} / \mathrm{l}$ ) in sick patients with septic shock, whereas TNF- $\alpha$ values were $6 \mathrm{ng} / \mathrm{l}$ (range, 4.1-14.9 ng/l) in controls and $28.8 \mathrm{ng} / \mathrm{l}$ (range, 9.1-94.1 ng/l) in sick patients, respectively $(10,27)$.

Transfection conditions and assays in endogenous deiodinase-expressing cell lines. Transfection studies were performed using D1-, D2-, or D3-expressing plasmids (100 ng) transiently expressed in HEK-293 cells using lipofectamine reagent according to the manufacturers' instructions (Invitrogen by Life Technologies). A thymidine kinase-human growth hormone (TK-hGH) plasmid was used to confirm that transfection occurred at a constant efficiency, as described previously (63). 48 hours after transfection, cells in 6-well plates were washed twice with sterile PBS and then cultured for 24 hours in $1 \mathrm{ml}$ serum-free $0.1 \% \mathrm{BSA}$ (resulting in an $\mathrm{FT}_{4}$ fraction of $2.7 \%$; ref. 64) in DMEM plus variable $\mathrm{T}_{4}$ concentrations (total $\mathrm{T}_{4}, 74-740 \mathrm{pM}$; $\mathrm{FT}_{4}, 2-20 \mathrm{pM}$ ), including approximately $100,000 \mathrm{cpm} / \mathrm{ml}\left[{ }^{125} \mathrm{I}\right] \mathrm{T}_{4}$. Endogenous D1- or D2-expressing cells were grown in 6-well plates and cultured under similar conditions. For the studies with D3, cells in 6-well plates were cultured for 24 hours in $1 \mathrm{ml}$ serum-free $0.5 \%$ BSA (resulting in an $\mathrm{FT}_{3}$ fraction of 3.5\%; ref. 65) in DMEM plus $195 \mathrm{pM} \mathrm{T}_{3}\left(\mathrm{FT}_{3}, \sim 7 \mathrm{pM}\right)$, including approximately $200,000 \mathrm{cpm} / \mathrm{ml}\left[{ }^{125} \mathrm{I}\right] \mathrm{T}_{3}$. All experiments were performed in duplicate or triplicate for each condition.

5 'Deiodinase assay. For measurements of activity in cell sonicates, the medium was removed, and cells were washed twice with PBS, harvested, and sonicated in $0.25 \mathrm{M}$ sucrose in PE buffer $(0.1 \mathrm{M}$ potassium phosphate and $1 \mathrm{mM}$ EDTA) with $10 \mathrm{mM}$ DTT. We used 50-100 $\mu \mathrm{g}$ cell sonicate: $100,000 \mathrm{cpm}\left[{ }^{125} \mathrm{I}\right] \mathrm{T}_{4}, 20 \mathrm{mM}$ DTT, and $5 \mu \mathrm{M}$ (for D1) or $4 \mathrm{nM} \mathrm{T}_{4}$ (for D2) in a final volume of $300 \mu \mathrm{lPE}$. These concentrations are approximately 2.5 times the estimated $K_{m}\left(\mathrm{~T}_{4}\right)$ for D1 $(2 \mu \mathrm{M})$ and 2 times the estimated $K_{m}$ $\left(\mathrm{T}_{4}\right)$ for D2 $(2 \mathrm{nM})$. Incubation was for 120 minutes at $37^{\circ} \mathrm{C}$, and ${ }^{125} \mathrm{I}^{-}$was separated from labeled $\mathrm{T}_{4}$ by adding $200 \mu \mathrm{l}$ horse serum and $100 \mu 150 \%$ trichloroacetic acid (TCA) followed by centrifugation at 12,000 $\mathrm{g}$ for $2 \mathrm{~min}$ utes $(16,65)$. D2 activity was completely blocked by the addition of $100 \mathrm{nM}$
$\mathrm{T}_{4}$ to the reaction, whereas $\mathrm{D} 1$ activity was inhibited by $10 \mathrm{mM}$ propylthiouracil (PTU). The ${ }^{125} \mathrm{I}^{-}$generated was expressed as the fraction of the total $\mathrm{T}_{4}$ counts minus the nonspecific deiodination in untransfected control cells ( $<5 \%$ of total $\left[{ }^{125} \mathrm{I}\right] \mathrm{T}_{4}$ counts) and corrected for the $50 \%$ reduction of specific activity relative to $\mathrm{T}_{4}$.

Deiodinase activity for D1 or D2 in intact cells was assayed as described previously (5). Briefly, at the completion of the experiment, we added $200 \mu \mathrm{l} \mathrm{horse}$ serum to $300 \mu \mathrm{l}$ medium and then added $100 \mu 1$ 50\% TCA. After vortexing, tubes were centrifuged at $12,000 \mathrm{~g}$ for 2 minutes. The ${ }^{125} \mathrm{I}^{-}$generated was expressed as the fraction of the total $\mathrm{T}_{4}$ counts minus the nonspecific deiodination in untransfected control cells ( $<5 \%$ of total $\left[{ }^{125} \mathrm{I}\right] \mathrm{T}_{4}$ counts) and corrected for the $50 \%$ reduction in the specific activity relative to $T_{4}$. Net $\mathrm{T}_{3}$ production was calculated by multiplying the fractional conversion by the $\mathrm{T}_{4}$ concentration in the media $(74$ or $740 \mathrm{pM})$ and expressed as total $\mathrm{T}_{3}$ production/mg protein per 24 hours. We have previously demonstrated by HPLC that net iodide release in this system is specific and equivalent to $T_{3}$ production, with the only exception being skeletal muscle $(5,16,66)$.

$D 3$ assays. D3 activity in cell sonicates was determined using paper chromatography as previously described (refs. 67 and 68). Cells were harvested and sonicated with $10 \mathrm{mM}$ Tris-HCl, 0.25 sucrose buffer ( $\mathrm{pH} 7.5$ ). Soni-

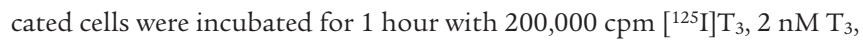
and $20 \mathrm{mM}$ DTT. The reaction was stopped by adding $200 \mu \mathrm{l}$ ethanol $95 \%$, $50 \mu \mathrm{l} \mathrm{NaOH} 0.04 \mathrm{~N}$, and $5 \mathrm{mg}$ PTU. Deiodination was determined based on the amount of $\left[{ }^{125} \mathrm{I}\right] \mathrm{T}_{2}$ produced after separation of reaction products by paper chromatography. Results were presented as the mean values derived from at least 2 independent experiments.

Sephadex LH-20 chromatography was used to measure the D3 activity in intact cells $(33,34,69)$. Briefly, at completion of the experiment, $300 \mu \mathrm{l}$ medium was collected, and the reaction was stopped with $200 \mu$ horse serum and $100 \mu \mathrm{l} 50 \% \mathrm{TCA}$, followed by centrifugation at $12,000 \mathrm{~g}$ for 2 minutes to precipitate the nonmetabolized $\left[{ }^{125} \mathrm{I}\right] \mathrm{T}_{3}$. The supernatant was used for the determination of $\left[{ }^{125} \mathrm{I}\right] \mathrm{T}_{2}$ and $\left[{ }^{125} \mathrm{I}\right] \mathrm{T}_{1}$ produced. The LH-20 column (bed volume, $2 \mathrm{ml}$ ) was equilibrated with $1: 10.1 \mathrm{M} \mathrm{HCl}$, an equal volume of $0.1 \mathrm{M} \mathrm{HCl}$ was added to $500-\mu \mathrm{l}$ samples, and the mixture was applied. Stepwise elution was done by successive application of $2 \times 1 \mathrm{ml}$ $0.1 \mathrm{M} \mathrm{HCl}$ (for ${ }^{125} \mathrm{I}^{-}$release), $6 \times 1 \mathrm{ml} 0.1 \mathrm{M} \mathrm{NaOH}$-ethanol $\left(8: 1 \mathrm{v} / \mathrm{v}\left[{ }^{125} \mathrm{I}\right]\right.$ for $\mathrm{T}_{1}$ release), and $4 \times 1 \mathrm{ml} 50 \%$ ethanol in $0.1 \mathrm{M} \mathrm{NaOH}\left(1: 1 \mathrm{v} / \mathrm{v}\left[{ }^{125} \mathrm{I}\right]\right.$ for $\mathrm{T}_{2}$ release). The $1-\mathrm{ml}$ fractions were collected and counted for radioactivity. Nonspecific deiodination was less than $1.5 \%$. Net D3 activity was calculated by multiplying the fractional conversion by the $\mathrm{T}_{3}$ concentration in the media and expressed as $\mathrm{T}_{3}$ inactivation (fmol/mg protein per 24 hours). The reaction was saturated by excess unlabeled $T_{3}$.

Determination of ROS production. Intracellular ROS production was performed by staining cells with CM-H2-DCFDA (Invitrogen), which is permeable to the cell membrane. A stock solution of the dye was reconstituted in molecular-grade DMSO to a concentration of $1 \mathrm{mM}$ immediately before use. After removing growth medium and washing cells with prewarmed PBS, 70\% confluent HEK-293, MCF-7, HepG2, or MSTO-211 cells on 6-well plates were incubated at $37^{\circ} \mathrm{C}$ for 30 minutes with prewarmed PBS containing DCFDA at a final concentration of $5 \mu \mathrm{M}$. Cells were scraped, centrifuged at $380 \mathrm{~g}$ for 3 minutes, resuspended, and counted. 12,000 cells were then incubated at $37^{\circ} \mathrm{C}$ for 1 hour with $500,1,000$, or $2,000 \mathrm{ng} / \mathrm{l} \mathrm{IL-6}$ or $100 \mu \mathrm{M} \mathrm{H}_{2} \mathrm{O}_{2}$, used as a positive control. The same number of cells was used as negative control. Fluorescence was measured using excitation and emission wavelengths of $490 \mathrm{~nm}$ and $535 \mathrm{~nm}$, respectively. Samples were run in triplicate. Data were expressed as fold increase in fluorescence compared with buffer-treated control cells.

Reduced GSH assay. GSH levels were measured according to a standard method $(16,70)$. Briefly, cells in culture dishes were washed with PBS and harvested in the presence of $300 \mu \mathrm{l}$ of $20 \mathrm{mM}$ sodium phosphate and 
$140 \mathrm{mM} \mathrm{KCl}$ buffer (pH 7.4). For the assay of extracellular GSH, $150 \mu \mathrm{l}$ of the medium was used. Proteins were precipitated by adding sodium metaphosphoric acid to a final concentration of 1:1. Samples of cells and medium were centrifuged for 10 minutes at 7,000 g. $15 \mu \mathrm{l}$ cell or medium preparation was incubated with an equal volume of o-phthaldialdehyde $(1 \mathrm{mg} / \mathrm{ml}$ methanol) at room temperature for 15 minutes in the presence of 20 volumes $(1: 20, \mathrm{v} / \mathrm{v})$ of $100 \mathrm{mM}$ sodium phosphate buffer ( $\mathrm{pH} 8.0)$ containing $5 \mathrm{mM}$ EDTA. Fluorescence was measured using excitation and emission wavelengths of $350 \mathrm{~nm}$ and $420 \mathrm{~nm}$, respectively. The calibration curve was performed with standard GSH (0.001-0.1 mM), and GSH concentrations were calculated as $\mathrm{nmol} / \mathrm{ml}$ (extracellular levels) or $\mathrm{nmol} / \mathrm{mg}$ protein (intracellular levels).

Real-time PCR. Total RNA was extracted from TT, MSTO-211, and MCF-7 cells with an RNeasy kit (Qiagen) and used to synthesize cDNA (SuperScript First-Strand Synthesis System for RT-PCR; Invitrogen). The generated cDNAs were used in a real-time PCR with a SYBR Green PCR Master Mix (Applied Biosystems) in ABI Prism 7500 Sequence Detection System (Applied Biosystems). Standard curves representing 5-point serial dilution of cDNA of the experimental and control groups were analyzed and used as calibrators of the relative quantification of product generated in the exponential phase of the amplification curve. The $r^{2}$ was greater than 0.99 , and the amplification efficiency varied between $80 \%$ and $100 \%$. Samples were measured by relative quantification (change in expression in the experimental group versus control; untreated versus treated cells). The data generated by ABI Prism 7500 system SDS software (Applied Biosystems) were then transferred to an Excel spreadsheet (Microsoft), and the experimental values were corrected to that of the cyclophilin A standard. The oligonucleotides used were the following: human D1, 5'-AAGAGGCTCTGGGTGCTCTTGG-3' and 5'-GGTTCTGGTGATTTCTGATGTC-3'; human D2, 5'-ACTTCCTGCTGGTCTA-
CATTGATG-3' and $5^{\prime}$-CTTCCTGGTTCTGGTGCTTCTTC-3'; human D3, 5' -TCCAGAGCCAGCACATCCT-3' and 5'-ACGTCGCGCTGGTACTTAGTG-3'; cyclophilin A (internal control), $5^{\prime}$-GTCAACCCCACCGT-

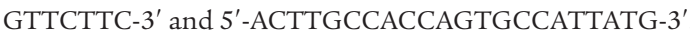

Statistics. Unless otherwise specified, results are presented as mean \pm SD. Data were analyzed using 2-tailed Student's $t$ test or 1-way ANOVA followed by post-hoc Duncan multiple-range tests when $F$ was significant. Linear regression analysis was also used to test concentration-dependent effects. Prism 5.0 software was used for statistical analysis; a $P$ value less than 0.05 was considered significant.

\section{Acknowledgments}

We thank Moacir Wajner (Instituto de Ciências Básicas da Saúde, UFRGS) for assistance with GSH experiments and Valerie Galton (Dartmouth Medical School, Lebanon, New Hampshire, USA) for assistance with paper chromatography D3 assays. Grant support was provided by Coordenação de Aperfeiçoamento de Pessoal de Nível Superior (CAPES), Conselho Nacional de Desenvolvimento Científico e Tecnológico (CNPq), Fundação de Apoio a Pesquisa do Rio Grande do Sul (FAPERGS), and Fundo de Incentivo a Pesquisa do Hospital de Clínicas (FIPE) of Brazil, as well as by NIH grants FIC TW007559 and DK 36256.

Received for publication November 16, 2010, and accepted in revised form February 16, 2011.

Address correspondence to: Ana Luiza Maia, Serviço de Endocrinologia, Hospital de Clínicas de Porto Alegre, Rua Ramiro Barcelos, 2350, CEP 90035-003, Porto Alegre, RS, Brasil. Phone: 55.51.33310207; Fax: 55.51.33325188; E-mail: almaia@ufrgs.br.
1. Larsen PR, Davies TF, Schlumberger MJ, Hay IA. Thyroid physiology and diagnostic evaluation of patients with thyroid disorders. In: Kronenberg HM, Melmed S, Polonsky KS, Larsen PR, eds. Williams Textbook of Endocrinology. Philadelphia, Pennsylvania, USA: Saunders Elsevier; 2008:439-442.

2. Adler SM, Wartofsky L. The nonthyroidal illness syndrome. Endocrinol Metab Clin North Am. 2007;36(3):657-672.

3. Peeters RP, Wouters PJ, van Toor H, Kaptein E, Visser TJ, Van den Berghe G. Serum 3,3',5'-triiodothyronine (rT3) and 3,5,3'-triiodothyronine/rT3 are prognostic markers in critically ill patients and are associated with postmortem tissue deiodinase activities. J Clin Endocrinol Metab. 2005;90(8):4559-4565.

4. Iervasi G, et al. Low-T3 syndrome: a strong prognostic predictor of death in patients with heart disease. Circulation. 2003;107(5):708-713.

5. Maia AL, Kim BW, Huang SA, Harney JW, Larsen PR. Type 2 iodothyronine deiodinase is the major source of plasma T3 in euthyroid humans. J Clin Invest. 2005;115(9):2524-2533.

6. Kaptein EM, Robinson WJ, Grieb DA, Nicoloff JT. Peripheral serum thyroxine, triiodothyronine and reverse triiodothyronine kinetics in the low thyroxine state of acute nonthyroidal illnesses. A noncompartmental analysis. J Clin Invest. 1982;69(3):526-535

7. Chopra IJ. Clinical review 86: Euthyroid sick syndrome: is it a misnomer? J Clin Endocrinol Metab. 1997;82(2):329-334.

8. Peeters RP, Wouters PJ, Kaptein E, van Toor H, Visser TJ, Van den Berghe G. Reduced activation and increased inactivation of thyroid hormone in tissues of critically ill patients. J Clin Endocrinol Metab. 2003;88(7):3202-3211.

9. St Germain DL, Galton VA, Hernandez A. Minireview: Defining the roles of the iodothyronine deiodinases: current concepts and challenges. Endocri- nology. 2009;150(3):1097-1107.

10. Rodriguez-Perez A, et al. Identification of molecular mechanisms related to nonthyroidal illness syndrome in skeletal muscle and adipose tissue from patients with septic shock. Clin Endocrinol (Oxf). 2008;68(5):821-827.

11. Mebis L, Langouche L, Visser TJ, Van den Berghe G. The type II iodothyronine deiodinase is up-regulated in skeletal muscle during prolonged critical illness. J Clin Endocrinol Metab. 2007;92(8):3330-3333.

12. Larsen PR. Type 2 iodothyronine deiodinase in human skeletal muscle: new insights into its physiological role and regulation. J Clin Endocrinol Metab. 2009;94(6):1893-1895.

13. Goswami A, Rosenberg IN. Thioredoxin stimulates enzymatic outer ring monodeiodination of reverse triiodothronine. Endocrinology. 1987;121(6):1937-1945.

14. Sharifi J, St Germain DL. The cDNA for the type I iodothyronine 5'-deiodinase encodes an enzyme manifesting both high $\mathrm{Km}$ and low Km activity. Evidence that rat liver and kidney contain a single enzyme which converts thyroxine to 3,5,3'-triiodothyronine. J Biol Chem. 1992;267(18):12539-12544.

15. St Germain DL. The effects and interactions of substrates, inhibitors, and the cellular thiol-disulfide balance on the regulation of type II iodothyronine 5'deiodinase. Endocrinology. 1988;122(5):1860-1868.

16. Goemann IM, Gereben B, Harney JW, Zhu B, Maia AL, Larsen PR. Substitution of serine for proline in the active center of type 2 iodothyronine deiodinase substantially alters its in vitro biochemical properties with dithiothreitol but not its function in intact cells. Endocrinology. 2010;151(2):821-829.

17. Bartalena L, Brogioni S, Grasso L, Velluzzi F, Martino E. Relationship of the increased serum interleukin- 6 concentration to changes of thyroid function in nonthyroidal illness. J Endocrinol Invest. 1994;17(4):269-274.
18. Torpy DJ, Tsigos C, Lotsikas AJ, Defensor R, Chrousos GP, Papanicolaou DA. Acute and delayed effects of a single-dose injection of interleukin-6 on thyroid function in healthy humans. Metabolism. 1998;47(10):1289-1293.

19. Boelen A, Platvoet-Ter Schiphorst MC, Wiersinga WM. Association between serum interleukin- 6 and serum 3,5,3'-triiodothyronine in nonthyroidal illness. J Clin Endocrinol Metab. 1993;77(6):1695-1699.

20. Boelen A, Platvoet-Ter Schiphorst MC, Wiersinga WM. Soluble cytokine receptors and the low 3,5,3'-triiodothyronine syndrome in patients with nonthyroidal disease. J Clin Endocrinol Metab. 1995;80(3):971-976.

21. Davies PH, Black EG, Sheppard MC, Franklyn JA. Relation between serum interleukin- 6 and thyroid hormone concentrations in 270 hospital inpatients with non-thyroidal illness. Clin Endocrinol (Oxf). 1996;44(2):199-205.

22. Friberg L, Werner S, Eggertsen G, Ahnve S. Rapid down-regulation of thyroid hormones in acute myocardial infarction: is it cardioprotective in patients with angina? Arch Intern Med. 2002; 162(12):1388-1394.

23. Yu J, Koenig RJ. Regulation of hepatocyte thyroxine 5'-deiodinase by T3 and nuclear receptor coactivators as a model of the sick euthyroid syndrome. J Biol Chem. 2000;275(49):38296-38301.

24. Jakobs TC, Mentrup B, Schmutzler C, Dreher I, Köhrle J. Proinflammatory cytokines inhibit the expression and function of human type I 5'-deiodinase in HepG2 hepatocarcinoma cells. Eur J Endocrinol. 2002;146(4):559-566.

25. Inada $\mathrm{M}$, et al. Estimation of thyroxine and triiodothyronine distribution and of the conversion rate of thyroxine to triiodothyronine in man. J Clin Invest. 1975;55(6):1337-1348.

26. Hosoi Y, Murakami M, Mizuma H, Ogiwara T, 
Imamura M, Mori M. Expression and regulation of type II iodothyronine deiodinase in cultured human skeletal muscle cells. J Clin Endocrinol Metab. 1999;84(9):3293-3300.

27. Mönig H, Arendt T, Meyer M, Kloehn S, Bewig B. Activation of the hypothalamo-pituitary-adrenal axis in response to septic or non-septic diseasesimplications for the euthyroid sick syndrome. Intensive Care Med. 1999;25(12):1402-1406.

28. Meyer EL, Goemann IM, Dora JM, Wagner MS, Maia AL. Type 2 iodothyronine deiodinase is highly expressed in medullary thyroid carcinoma. Mol Cell Endocrinol. 2008;289(1-2):16-22.

29. Curcio C, et al. The human type 2 iodothyronine deiodinase is a selenoprotein highly expressed in a mesothelioma cell line. J Biol Chem. 2001; 276(32):30183-30187.

30. Lamirand A, Pallud-Mothré S, Ramaugé M, Pierre $\mathrm{M}$, Courtin F. Oxidative stress regulates type 3 deiodinase and type 2 deiodinase in cultured rat astrocytes. Endocrinology. 2008;149(7):3713-3721.

31. Meier B, et al. Human fibroblasts release reactive oxygen species in response to interleukin-1 or tumour necrosis factor-alpha. Biochem J. 1989; 263(2):539-545.

32. Haddad JJ, Land SC. Redox/ROS regulation of lipopolysaccharide-induced mitogen-activated protein kinase (MAPK) activation and MAPKmediated TNF-alpha biosynthesis. BrJ Pharmacol. 2002;135(2):520-536

33. Rutgers M, Bonthuis F, de Herder WW, Visser TJ. Accumulation of plasma triiodothyronine sulfate in rats treated with propylthiouracil. J Clin Invest. 1987;80(3):758-762.

34. Peeters R, et al. Regional physiological adaptation of the central nervous system deiodinases to iodine deficiency. Am J Physiol Endocrinol Metab. 2001;281(1):E54-E61.

35. Baigi MG, et al. Apoptosis/necrosis switch in two different cancer cell lines: influence of benzoquinone- and hydrogen peroxide-induced oxidative stress intensity, and glutathione. Toxicol In Vitro. 2008;22(6):1547-1554.

36. Toyoda N, Harney JW, Berry MJ, Larsen PR. Identification of critical amino acids for 3,5,3'-triiodothyronine deiodination by human type 1 deiodinase based on comparative functional-structural analyses of the human, dog, and rat enzymes. J Biol Chem. 1994;269(32):20329-20334.

37. Baqui MM, Gereben B, Harney JW, Larsen PR, Bianco AC. Distinct subcellular localization of transiently expressed types 1 and 2 iodothyronine deiodinases as determined by immunofluorescence confocal microscopy. Endocrinology. 2000;141(11):4309-4312.

38. Baqui $\mathrm{M}$, et al. Human type 3 iodothyronine selenodeiodinase is located in the plasma membrane and undergoes rapid internalization to endosomes. J Biol Chem. 2003;278(2):1206-1211.

39. Haddad JJ, Harb HL. L-gamma-Glutamyl-L-cysteinyl-glycine (glutathione; GSH) and GSH-related enzymes in the regulation of pro- and anti-inflammatory cytokines: a signaling transcriptional scenario for $\operatorname{redox}(\mathrm{y})$ immunologic sensor(s)? $\mathrm{Mol}$ Immunol. 2005;42(9):987-1014.
40. Valko M, Leibfritz D, Moncol J, Cronin MT, Mazur $\mathrm{M}$, Telser J. Free radicals and antioxidants in normal physiological functions and human disease. Int J Biochem Cell Biol. 2007;39(1):44-84.

41. Schafer FQ, Buettner GR. Redox environment of the cell as viewed through the redox state of the glutathione disulfide/glutathione couple. Free Radic Biol Med. 2001;30(11):1191-1212.

42. Abilés J, et al. Oxidative stress is increased in critically ill patients according to antioxidant vitamins intake, independent of severity: a cohort study. Crit Care. 2006;10(5):R146.

43. Hammarqvist F, Luo JL, Cotgreave IA, Andersson K, Wernerman J. Skeletal muscle glutathione is depleted in critically ill patients. Crit Care Med. 1997;25(1):78-84.

44. Haddad JJ. Redox regulation of pro-inflammatory cytokines and IkappaB-alpha/NF-kappaB nuclear translocation and activation. Biochem Biophys Res Commun. 2002;296(4):847-856.

45. Papp LV, Lu J, Striebel F, Kennedy D, Holmgren A, Khanna KK. The redox state of SECIS binding protein 2 controls its localization and selenocysteine incorporation function. Mol Cell Biol. 2006;26(13):4895-4910.

46. Linke K, Jakob U. Not every disulfide lasts forever: disulfide bond formation as a redox switch. Antioxid Redox Signal. 2003;5(4):425-434.

47. Lu J, Holmgren A. Selenoproteins. J Biol Chem. 2009;284(2):723-727.

48. Kuiper GG, Klootwijk W, Visser TJ. Substitution of cysteine for a conserved alanine residue in the catalytic center of type II iodothyronine deiodinase alters interaction with reducing cofactor. Endocrinology. 2002;143(4):1190-1198.

49. Steinsapir J, Bianco AC, Buettner C, Harney J, Larsen PR. Substrate-induced down-regulation of human type 2 deiodinase (hD2) is mediated through proteasomal degradation and requires interaction with the enzyme's active center. Endocrinology. 2000;141(3):1127-1135.

50. Takahashi-Tezuka M, et al. Gab1 acts as an adapter molecule linking the cytokine receptor gp130 to ERK mitogen-activated protein kinase. Mol Cell Biol. 1998;18(7):4109-4117.

51. Sano M, et al. ERK and p38 MAPK, but not NF$\mathrm{kappaB}$, are critically involved in reactive oxygen species-mediated induction of IL- 6 by angiotensin II in cardiac fibroblasts. Circ Res. 2001; 89(8):661-669.

52. Zauberman A, Zipori D, Krupsky M, Ben-Levy R. Stress activated protein kinase p38 is involved in IL-6 induced transcriptional activation of STAT3. Oncogene. 1999;18(26):3886-3893.

53. Dimova EY, Samoylenko A, Kietzmann $\mathrm{T}$. FOXO4 induces human plasminogen activator inhibitor-1 gene expression via an indirect mechanism by modulating HIF-1alpha and CREB levels. Antioxid Redox Signal. 2010;13(4):413-424.

54. Martinez-deMena R, Obregón MJ. Insulin increases the adrenergic stimulation of 5' deiodinase activity and mRNA expression in rat brown adipocytes; role of MAPK and PI3K. J Mol Endocrinol. 2005;34(1):139-151.
55. Pekary AE, Berg L, Santini F, Chopra I, Hershman JM. Cytokines modulate type I iodothyronine deiodinase mRNA levels and enzyme activity in FRTL-5 rat thyroid cells. Mol Cell Endocrinol. 1994; 101(1-2):R31-R35.

56. Gereben B, Goncalves C, Harney JW, Larsen PR, Bianco AC. Selective proteolysis of human type 2 deiodinase: a novel ubiquitin-proteasomal mediated mechanism for regulation of hormone activation. Mol Endocrinol. 2000;14(11):1697-1708.

57. O'Mara BA, Dittrich W, Lauterio TJ, St Germain DL. Pretranslational regulation of type I 5'deiodinase by thyroid hormones and in fasted and diabetic rats. Endocrinology. 1993;133(4):1715-1723.

58. Olivares EL, et al. Thyroid function disturbance and type 3 iodothyronine deiodinase induction after myocardial infarction in rats a time course study. Endocrinology. 2007;148(10):4786-4792.

59. Kwakkel J, et al. Skeletal muscle deiodinase type 2 regulation during illness in mice. J Endocrinol. 2009;203(2):263-270.

60. Redout EM, et al. Antioxidant treatment attenuates pulmonary arterial hypertension-induced heart failure. Am J Physiol Heart Circ Physiol. 2010; 298(3):H1038-H1047.

61. Meister A, Anderson ME. Glutathione. Annu Rev Biochem. 1983;52:711-760

62. Everts ME, et al. Uptake of thyroxine in cultured anterior pituitary cells of euthyroid rats. Endocrinology. 1994;134(6):2490-2497.

63. Brent GA, Larsen PR, Harney JW, Koenig RJ, Moore DD. Functional characterization of the rat growth hormone promoter elements required for induction by thyroid hormone with and without a cotransfected beta type thyroid hormone receptor. J Biol Chem. 1989;264(1):178-182.

64. Verhoeven FA, Van der Putten HH, Hennemann G, Lamers JM, Visser TJ, Everts ME. Uptake of triiodothyronine and triiodothyroacetic acid in neonatal rat cardiomyocytes: effects of metabolites and analogs. J Endocrinol. 2002;173(2):247-255.

65. Dentice $\mathrm{M}$, et al. The FoxO3/type 2 deiodinase pathway is required for normal mouse myogenesis and muscle regeneration. J Clin Invest. 2010; 120(11):4021-4030.

66. Marsili A, et al. Type 2 iodothyronine deiodinase levels are higher in slow-twitch than fast-twitch mouse skeletal muscle and are increased in hypothyroidism. Endocrinology. 2010;151(12):5952-5960.

67. Hernandez A, Martinez ME, Fiering S, Galton VA, St Germain D. Type 3 deiodinase is critical for the maturation and function of the thyroid axis. J Clin Invest. 2006;116(2):476-484.

68. Galton VA, Schneider MJ, Clark AS, St Germain DL. Life without thyroxine to 3,5,3'-triiodothyronine conversion: studies in mice devoid of the 5 '-deiodinases. Endocrinology. 2009;150(6):2957-2963.

69. Mol JA, Visser TJ. Rapid and selective inner ring deiodination of thyroxine sulfate by rat liver deiodinase. Endocrinology. 1985;117(1):8-12.

70. Tonin AM, et al. Long-chain 3-hydroxy fatty acids accumulating in LCHAD and MTP deficiencies induce oxidative stress in rat brain. Neurochem Int. 2010;56(8):930-936. 